\title{
Türkiye Muhasebe Standartlarının (TMS) Türk Sigortacılık Sektörü Üzerine Etkileri ${ }^{1}$
}

\author{
Erol YENER \\ Sorumlu Yazar, Çankırı Karatekin Üniversitesi, IIIBF, Işsletme Bölümü. \\ erolyener@karatekin.edu.tr, ORCID:0000-0001-9186-1874 \\ Gürcühan CENGIZ \\ Cankırı Karatekin Üniversitesi, SBE. \\ gurcuhan@karatekin.edu.tr, ORCID:0000-0001-5844-2838
}

\begin{abstract}
$\ddot{\mathbf{O z}}$
Bu çalışmanın temel amacı, Türkiye Muhasebe Standartlarının (TMS) Türk sigorta sektörü üzerine etkilerinin analiz edilmesidir. Çalışmanın amacı doğrultusunda, 2003-2017 yılları arasında hayat dışı branşlarda faaliyet gösteren sigorta şirketlerinin sektöre özgü 20 adet temel finansal oranının ortalamaları alınarak, yıllar itibariyle karşılaştırmalı olarak hesaplanmıştır. Daha sonra bu oranlarda, TMS öncesi (2003-2007) ve sonrası (2007-2017) dönemler için istatistiksel açıdan anlamlı bir fark olup olmadığı incelenmiş ve anlamlılık düzeyleri test edilmiştir. Çalışmada istatistiksel veri analizi yöntemi olarak, "Finansal Oran Analizi" ve "Wilcoxon İşaretli Sıralar Testi” kullanılmıştır. Veriler SPSS 20.0 paket programı aracılığı ile analiz edilmiştir. Analiz sonucunda elde edilen bulgulara göre, sigorta sektöründe faaliyet gösteren şirketlerin analizinde kullanılan finansal oranların \%65'inde (13/20) TMS öncesi ve sonrası dönemler arasında ve sektörel bazda belirli anlamlılık düzeylerinde istatistiksel olarak anlamlı bir farklılık tespit edilmiştir.
\end{abstract}

Anahtar Kelimeler: TMS, Sigorta Sektörü, Finansal Oranlar, Finansal Analiz

JEL Sınıflandırma Kodları: C14, G22

\section{The Effects of Turkish Accounting Standards (TMS) on Turkish Insurance Sector ${ }^{2}$}

\begin{abstract}
The main aim of this study is to analyze the effects of Turkish Accounting Standards on Turkish insurance sector. For the purpose of this study, the average of 20 basic financial ratios of insurance companies operating in non-life branches were calculated between 2003 and 2017 and compared within these years. Then these ratios for the periods prior to TMS (2003-2007) and after TMS (2007-2017) were examined whether there was a statistically significant difference between these periods and their significant levels are tested. Financial ratio analysis and Wilcoxon Signed Ranks Test were used as statistical data analysis methods. The data were analyzed by SPSS 20.0 package program. According to the results of the analysis, a statistically significant difference at the specific significance levels was found in the 13 financial ratios (\%65) of the companies operating in the insurance sector between the pre- and post-TMS periods and on the sectoral basis.
\end{abstract}

Keywords: TMS, Insurance Sector, Financial Ratios, Financial Analysis

JEL Classification Codes: C14, G22

\footnotetext{
${ }^{1} \mathrm{Bu}$ çalışma, Gürcühan Cengiz'in Çankırı Karatekin Üniversitesi Sosyal Bilimler Enstitüsü’nde Dr. Öğr. Üyesi Erol Yener danışmanlığında tamamlanan "Türkiye Muhasebe Standartlarının (TMS) Türk Sigortacılık Sektörü Üzerindeki Etkilerinin İncelenmesine Yönelik Bir Araştırma" başlıklı yüksek lisans tezinden üretilmiştir.

${ }^{2}$ Extended abstract is presented at the end of the article.

Geliş Tarihi (Received): 02.10.2019 - Kabul Edilme Tarihi (Accepted): 04.06.2020
}

Atıfta bulunmak için/Cite this paper:

Yener, E. ve Cengiz, G. (2020) Türkiye Muhasebe Standartlarının (TMS) Türk Sigortacılık Sektörü Üzerine Etkileri. Çankırl Karatekin Üniversitesi IIBBF Dergisi, 10 (1), 211-243. Doi: 10.18074/ckuiibfd.628624 


\section{Giriş}

Sigorta sektörü, bir taraftan kısa vadede ortaya çıkabilecek risklere karşı gerçek ve tüzel kişiler için güvence mekanizması sağlarken, diğer taraftan uzun vadede oluşturduğu fonlarla finansal piyasalara önemli oranda kaynak aktarmaktadır. Böylelikle sektör, ekonomik aktivitelerin gelişmesinde önemli bir rol üstlenmekte; sektörde faaliyet gösteren sigorta şirketleri, uluslararası ticaretin gelişmesine, vergi gelirlerinin artmasına, ekonomide kayıt dişılığın azalmasına, toplumun refah seviyesinin ve tasarrufların artmasına doğrudan katkı sağlamaktadır.

Türkiye'de finans sektöründe mali kuruluşlar olarak faaliyet gösteren sigorta şirketlerinin genel ekonomi içerisindeki yeri oldukça önemlidir. Son yıllarda meydana gelen finansal krizlerin neredeyse tamamının finans sektörü kaynaklı olması, ülkeleri bu alanda tedbir alma yoluna itmiş; bu doğrultuda finans sektöründeki krizlerin önlenebilmesi için sektörde yer alan diğer mali kuruluşların yanında sigorta sektöründe faaliyet gösteren şirketlerin de güçlü bir mali yapıya kavuşması önemli hale gelmiştir.

Temel olarak ele alındığında sigorta sektörünün faaliyet alanını maddi varlıklardan çok maddi olmayan varlıklar oluşturur. Bu durumun doğal sonucu olarak, sigorta şirketleri, üretim ve ticaret (satış ve pazarlama) sektöründe faaliyet gösteren şirketlerden önemli ölçüde farklılık arz ederler. Ayrıca sigorta şirketleri finans sektöründe faaliyet göstermelerine rağmen, varlık ve yükümlülük yapısı itibari ile diğer finansal kurumlardan da farklı özellikler taşımaktadır. Sektörün sahip olduğu bu farkl1lıklar, sigorta şirketlerinin muhasebe sistemlerine, finansal yapılarına ve tablolarına da yansımakta; bu anlamda sigorta sektörü diğer sektörlerden farklı muhasebe uygulamalarına ve finansal raporlamaya ihtiyaç duymaktadır.

$\mathrm{Bu}$ ihtiyacın karşılanmasına yönelik olarak geliştirilen standartlaştırılmış muhasebe çalışmaları, dünya ile paralel olarak Türkiye'de de yürürlüğe girmiştir. Bu bağlamda öncelikli olarak yaşanan küreselleşme hareketleri neticesinde ortak bir muhasebe dilinin yaratılması zorunluluğu ortaya çıkmış; buna istinaden tüm ülkelerde uygulanmakta olan çeşitli muhasebe ilkelerini veya kurallarını yeknesaklaştırabilmek ve evrensel muhasebe sistemi oluşturabilmek amaciyla Uluslararas1 Finansal Raporlama ve Muhasebe Standartları (UFRS-UMS) yayımlanmıştır. $\mathrm{Bu}$ standartların yayımlanmasına müteakip ülkeler kendi muhasebe sistemlerini bu standartlara uyumlaştırma çalışmaları kapsamında kendi iç muhasebe sistemlerini geliştirmiştir. Bunun neticesinde pek çok alanda olduğu gibi Türk sigorta sektöründe de muhasebe standartlarına yönelik yeni düzenlemelerin yapılması kaçınılmaz olarak gündeme gelmiş; bu bağlamda Hazine Müsteşarlığı ve Türkiye Muhasebe Standartları Kurulu tarafından 01.01.2008 tarihinde, "Sigorta ve Reasürans Şirketleri ile Emeklilik Şirketlerinin Finansal Raporlamaları Hakkında Yönetmelik” yayınlanarak yürürlüğe girmiştir. 
Böylelikle sigorta sektöründe faaliyet gösteren şirketler, UFRS ile uyumlu şekilde hazırlanan Türkiye Muhasebe Standartlarını (TMS) uygulamaya başlamışlardır.

$\mathrm{Bu}$ çalışma, yürürlüğe giren Türkiye Muhasebe Standartlarının (TMS) sigorta sektöründe faaliyet gösteren şirketler üzerinde herhangi bir etkisinin olup olmadığını ortaya kayabilmek amacıyla yapılmıştır. Bu kapsamda belirlenmiş oranlar üzerinden sektör analizi yapılarak TMS öncesi ve sonrası dönem karşılaştırılmıştır. Analizin istatistiki model bölümünde Wilcoxon İşaretli Sıralar Testi yöntemi kullanılmıştır. Analiz sonucunda TMS'nin hayata geçirilmesi neticesinde hayat dışı sigortacılık sektöründe APÖ (Alınan Primler/Top. Özsermaye Oranı), LVO (Likit Varlıklar/Varlık Toplamı Oranı), CO (Cari Oran), LO (Likidite Oran1), KO (Konservasyon Oran1), AKO (Arac1 Komisyon Oran1), TDO (Tazminat Tediye Oranı), MO (Masraf Oranı) BO'nun (Birleşik Oran), arttığı; buna karşılık, ÖVT (Özsermaye/Varlık Toplamı Oranı), ÖTK (Özsermaye/ Teknik Karşılıklar Oranı), SYO (Sermaye Yeterlilik Oranı), PRA (Prim ve Reasürans Alacakları/ Varlık Toplamı Oranı), TKKO (Teknik Karşılık Oranı), RKO (Reasürans Komisyon Oranı), ARO (Prim Artış Oranı), TKO(Teknik Karlılık Oranı) ve ÖKO'nun (Özsermaye Karlılık Oranı) azaldığı, HPO'da (Hasar Prim Oranı ) ise herhangi bir değişim olmadığı sonucuna ulaşılmıştır.

\section{Literatür Taraması}

Sigorta sektörü ile ilgili literatür incelendiğinde sigorta şirketlerinin finansal durumunu ve performansını inceleyen bir çok çalışmanın mevcut olduğu; buna karşılık TMS'nin sigorta sektörü üzerindeki etkisini inceleyen çalışma sayısının sınırlı olduğu görülür. TMS'nin sigorta sektörü üzerindeki etkisini inceleyen çalışmaların önemli bir kısmı belirli sayıda sigorta şirketinin verileri kullanılarak, finansal oran analizi yöntemiyle ve yıllar itibariyle karşılaştırmalı finansal analizin yapıldı̆̆ı çalışmalardır. Diğer taraftan, TMS'ye yönelik yapılan çalışmalar ise daha ziyade içerik analiziyle sınırlıdır. Dolayısıyla ülkemizde TMS'nin sigorta sektörü üzerindeki etkilerini inceleyen ampirik çalışma sayısının eksik olduğu sonucuna ulaşılmıştır. Bu kapsamda, sigorta sektörünün finansal analiziyle ilgili yapılmış çalışmalar aşağıda özetlenmiştir.

Ernst and Young (2006) tarafından yapılan çalışmada, değişik ülkelerde faaliyet gösteren on sekiz sigorta şirketinin muhasebe standartlarını uygulama düzeyleri ve yaklaşımları değerlendirilmiş; bu kapsamda 2005 yılına ait ve muhasebe standartları ile uyumlu finansal tablolar içerik analizi yöntemiyle incelenmiştir. Çalışma sonucunda, sigorta şirketlerinin muhasebe standartlarını 2005 yılından itibaren uygulamaya başladıkları tespit edilmiştir. Muhasebe standartlarına geçişin sigorta şirketlerine ek bir maliyet getirdiği; ayrıca standartların muhasebe uygulamalarını kolaylaştırmadığı, aksine finansal tablo kullanıcılarının işini zorlaştırdığı tespit edilmiştir. 
Hrechaniuk, vd. (2007) çalışmalarında Ukrayna, İspanya ve Litvanya'da faaliyet gösteren sigorta şirketlerinin finansal performanslarına etki eden faktörleri incelemişlerdir. Çalışma sonucunda, İspanya ve Litvanya'da bulunan sigorta şirketlerinin karlılık durumları ile hasar prim ve borçlanma oranları arasında istatistiksel açıdan negatif yönde; yatırım harcamaları ile pozitif yönde anlamlı bir ilişki bulmuşlardır. Ukrayna'da bulunan sigorta şirketlerinde ise varlık toplamları, yatırım harcamaları ve borçlanma oranı ile karlılık arasında istatistiksel açıdan pozitif yönde; hasar prim oranı ile karlılık arasında ise negatif yönde ve anlamlı bir ilişki tespit edilmiştir.

Al-Shami ve Ali (2008) çalışmalarında, Birleşik Arap Emirlikleri'nde 2004-2007 yılları arasında faaliyet gösteren sigorta şirketlerinin karlılıklarına etki eden faktörleri incelemişlerdir. Çalışmada, şirketlerinin kuruluş yılı ile aktif karlılık oranı arasında istatistiki açıdan anlamlı sonuç bulamamışlardır.

Dönmez (2008) çalışmasında, 2000-2006 yılları arasında BİST’de işlem gören sigorta şirketlerinin (Ak, Anadolu, Aviva, Güneş, Ray ve Yapı kredi Sigorta) verilerini kullanarak ve on adet finansal oran yardımıyla yıllar itibariyle karşılaştırmalı finansal oran analizi yapılmıştır. Çalışma sonucunda, sigorta sektörünün aktif kalitesi ve likiditeye ait finansal oranlarının 2000 yılında en yüksek, 2006 yılında ise en düşük seviyede olduğu belirlenmiştir.

Şişmanoğlu (2010), TMS'nin, sigorta sektöründe şeffaflığı arttırıp arttırmadığını, sigorta şirketlerine faydalarını ve sigorta şirketlerinin beklentilerini karşılayıp karşılamadığını incelemiş̧tir. Anket yöntemi, frekans dağılımı ve çapraz tablolar analiz yönteminin kullanıldığı çalışma sonucunda sigorta şirketlerinin, TMS konusunda eğitim almaları ve yabancı ortakları olması nedeniyle yeterli bilgi ve donanıma sahip oldukları, yeni uygulamalara hazır oldukları tespit edilmiştir.

Şenyiğit (2010), finansal raporlamayla ilgili uluslararası gelişmeleri ve özellikle de TMS'lerin Türk sigortacılık sektörü üzerindeki muhtemel etkilerini araştırmıştır. $\mathrm{Bu}$ kapsamda çalışmada, TMS uygulamalarıyla birlikte finansal tablolara etki eden muhasebe standartları araştırılmıştır. Ayrıca ülkemizde 2008 y1lı sonunda sigorta sektöründe faaliyet gösteren 43 sigorta şirketinin finansal raporlama uygulamaları incelenmiştir. İçerik analizi yönteminin kullanıldığı çalışma sonucunda, TMS'ye geçişin şirketlerin özsermayesi üzerinde etkili olduğu tespit edilmiştir. Diğer bir ifadeyle, TMS uygulamaları sonucunda şirketlerin \% 86'sının (37 şirket) özsermayesinin artırdı̆̆1, \% 14'nün (6 şirket) ise özsermayesinin azaldığı tespit edilmiştir. Bu sonuç, TMS uygulamalarının genellikle şirketlerin özsermayesini olumlu yönde etkilediğini göstermektedir.

Yılmaz (2010) çalışmasında, 2005-2009 yılları arasında BİST'te işlem gören ve hayat dışı branşta faaliyet gösteren 6 sigorta şirketinin finansal durumunu, şirket verilerinden yararlanarak ve bazı finansal oranlar kullanarak yıllar itibariyle karşılaştırmalı olarak analiz etmiştir. Çalışmada oran analizi tekniği kullanılmıştır. 
Çalışma sonucunda, analize dâhil edilen şirketlerin genel olarak likidite, karlılık ve sermaye yapısının güçlü olduğu tespit edilmiştir. Ayrıca şirketlerin borçlarını ödeyebilecek finansal güce sahip oldukları belirlenmiştir.

Leskay (2010) çalışmasında, sigorta sektörüyle ilgili teorik olarak bilgi vermiş ve sigorta şirketlerinin kullanmış oldukları finansal tabloları ve uygulanan finansal analiz tekniklerini açıklamıştır. Çalışmada, 2007-2008 yılları arasında hayat dışı (elementer) alanda faaliyet gösteren bir sigorta şirketinin verilerini kullanarak karşılaştırmalı, dikey ve oran analizi yöntemleri ile yıllar itibariyle karşılaştırmalı analiz yapmıştır. Çalışma sonucunda, sigorta sektöründe genel olarak likidite sıkıntısı yaşandığ 1 tespit edilmiştir. Ancak genel olarak sigorta şirketlerinin finansal durumlarının iyi durumda olduğu belirlenmiştir.

Akın ve Ece (2013) çalışmalarında, 2006-2010 yılları arasında BİST'te faaliyet gösteren 7 sigorta şirketinin finansal durumu ve performanslarını araştırmışlardır. Çalışmada, 2008 finansal krizinin finansal performans üzerindeki etkileri de araştırılmıştır. Çalışmanın uygulama bölümünde, sigorta şirketlerinin verilerinden yararlanılarak karşılaştırmalı oran analizi yöntemi kullanılmıştır. Çalışma sonucunda, finansal krizin sigorta şirketlerinin finansal durumunu olumsuz yönde etkilediği ve olumsuz büyüme hızına sahip oldukları tespit edilmiştir. Ayrıca analiz döneminde sigorta şirketlerinin karlılığının düşme eğiliminde olduğu belirlenmiştir.

Doğan (2013) çalışmasında, 2005-2011 dönemlerinde BİST'te işlem gören sigorta şirketlerinin sermaye yapıları ile karlılıkları arasındaki ilişkiyi incelemiştir. Çalışmada regresyon analizi yöntemi kullanılmıştır. Çalışma sonucunda, sigorta şirketlerinin varlık büyüklükleri ile karlılıkları arasında istatistiki açıdan pozitif; hasar prim ve borçlanma oranı ile karlılık arasında ise negatif yönlü bir ilişki olduğu tespit edilmiştir.

Süt (2014), 2009-2013 döneminde BİST’te işlem gören ve hayat dışı branşta faaliyet gösteren 6 sigorta şirketinin verilerinden yararlanarak ve bazı finansal oranlar kullanarak şirketlerin finansal performanslarını yıllar itibariyle karşılaştırmalı olarak analiz etmiştir. Çalışmada oran analizi tekniği kullanılmıştır. Çalışma sonucunda, sigorta şirketlerinin karlılıklarında dalgalanmalar olduğu tespit edilmiştir.

Ergin (2015) çalışmasında, 2008-2013 yılları arasında BİST'de işlem gören 6 sigorta şirketinden hangisine yatırım yapmanın daha uygun olduğunu araştırmıştır. Çalışmada, söz konusu sigorta şirketlerinin verilerini kullanarak ve bazı finansal oranlar yardımıyla yıllar itibariyle karşılaştırmalı analiz yapılmıştır. Çalışmada oran analizi tekniği kullanılmıştır. Çalışma sonucunda, hisse senetlerine yatırım yapmanın 2009 yılında uygun olmadığı, 2010-2013 yılları arasında ise daha uygun olduğu tespit edilmiştir. Son olarak, Türkiye'de üretilen 
prim üretiminin, gelişmiş ülkelerle kıyaslandığında geri olduğu, ancak son yıllarda sigorta sektörünün büyüme hızının oldukça arttığı belirlenmiştir.

Güleç (2015) çalışmasında, 2003-2014 yılları arasında sigorta sektöründe faaliyet gösteren 39 hayat dışı şirketin finansal yapısını incelemiştir. Bu kapsamda şirketlerin likidite, mali yapı, faaliyet etkinliği ve karlılıklarına ait 18 oran kullanarak yıllar itibariyle karşılaştırmalı analiz yapmıştır. Çalışmada oran analizi tekniği kullanılmıştır. Çalışma sonucunda, hayat dışı sigorta şirketlerinin kısa vadeli borçlarını ödeyebilme gücünde oldukları tespit edilmiştir. Ayrıca söz konusu şirketlerin son yıllarda karlılık durumunun istenilen seviyede olmadığ belirlenmiştir.

Çelik (2017) çalışmasında, 2013-2015 yılları arasında sigorta sektöründe faaliyet gösteren Ak, Anadolu ve AXA sigorta şirketlerinin verilerini kullanarak ve bazı finansal oranlar yardımıyla yıllar itibariyle karşılaştırmalı finansal analiz yapmıştır. Çalışmada oran, karşılaştırmalı, dikey ve trend analizleri kullanılmıştır. Çalışma sonucunda, Anadolu Sigorta'nın diğer şirketlere kıyasla nakit varlıklarını kısa vadeli borçlarla karşıladığı belirlenmiştir.

\section{Araştırmanın Metodolojisi}

Çalışmanın metodoloji bölümünde araştırmanın amacı, önemi, kapsamı, kısıtları ve yöntemine yönelik açıklamalar yapılmış olup, analize yönelik teorik bilgiler sunulmuştur. Daha sonra araştırmanın veri seti açıklanmıştır. Son olarak da TMS uygulamalarının sigorta sektörü üzerindeki muhtemel etkilerini tespit etmek amacıyla gerekli istatistiki analizler yapılmış ve yorumlanmıştır.

\subsection{Araştırmanın Amacı ve Önemi}

Sigortacılık faaliyetlerinin temelini belirli riskler oluşturduğu için, önceden belirlenemeyen veya ölçülemeyen risklerin meydana gelmesi durumunda şirketlerin varlıkları, borçlarını veya yükümlülüklerini karşılayamaz duruma gelebilmektedir. $\mathrm{Bu}$ bağlamda, sigorta faaliyetlerinden yararlananların menfaatlerini sağlamak için, sigorta şirketlerinin finansal durumlarının veya yapılarının güçlü olması gerekir (Acar, 2005, s. 5). Sigorta şirketlerinin finansal yapılarının güçlendirilmesi için hayata geçirilen düzenlemelerin temel amacı, şirketlerin müşterilerine karşı mali yükümlülüklerini karşılayamama riskini en aza indirmektir. Ancak sigorta şirketlerinin faaliyetlerinin gereği olarak, risklerin tamamen ortadan kaldırılması mümkün değildir. Riskleri en aza indirebilmek için birçok ülkede finansal raporlama ve muhasebe standartları geliştirilmiştir. Öte yandan, mali kuruluş olan sigorta şirketleri, sermaye gücü ve ekonomik gelişme açısından ülke piyasaları için çok önemlidir. Benzer şekilde sigorta şirketleri, topladıkları fonları finansal piyasada kullanmaları ve çeşitli yatırımlara dönüştürmeleri sayesinde ekonomik gelişimin sağlanması ve ülkelerin zenginleşmesi açısından büyük önem taşımaktadırlar. 
Ülkemizde finans sektörünün büyük bir kısmını, bankacılık sektöründen sonra sigorta sektörü oluşturmaktadır. Ayrıca ülkemizde, sigortacılık sektörünün bilanço büyüklüğü açısından bankacılık sektörünün oldukça gerisinde yer aldığ bilinmektedir. Ancak yıllar itibariyle ülkemiz sigortacılık sektörü gelişme potansiyelindedir. Sektör günümüzde istenilen seviyeye ulaşamamıştır. Bu durumun en önemli nedeni ise ülkemiz sigorta sektörünün yasal mevzuat alanındaki eksiklikler nedeniyle uzun zamandır yapısal sorunlar yaşamasıdır. $\mathrm{Bu}$ sorunların başında finansal raporlama ve muhasebe düzenlemeleri alanındaki eksiklik gelmektedir. Sigorta şirketlerinin faaliyetleri sonucunda oluşan finansal tabloların istenilen düzeyde ve yararlı olabilmesi için uluslararası düzenlemeler kapsamında hazırlanmış olmaları gerekmektedir.

Ülkemiz sigorta sektörüne yönelik ilk muhasebe standardı olan "TFRS 4 Sigorta Sözleşmeleri Standardı" 01.01.2005 tarihinde yayımlamıştır. Ancak bu standart, değerlemeye ilişkin hükümler içermeyen, geçici bir standarttır ve genellikle finansal tablo dipnotlarına yönelik hükümler içermektedir. $\mathrm{Bu}$ açıklamadan anlaşılacağ üzere TFRS 4, sigorta sektörüne çok fazla etkisi olmayan kısmi bir standarttır. Ülkemiz sigorta sektöründe faaliyet gösteren şirketler gerçek anlamda 2007 yılında Hazine Müsteşarlığı tarafından düzenlenen ve 01.01.2008 tarihinde UFRS'yle uyumlu hale getirilen muhasebe standartları seti olan, Türkiye Muhasebe Standartları Kurulu (TMSK) tarafindan yayımlanan Türkiye Muhasebe Standartlarını (TMS) uygulamaya başlamışlardır. Söz konusu standartlar sigorta faaliyetlerinin değerlendirilmesine yönelik tahmine dayalı ve karmaşık düzenlemeler getirmektedir. $\mathrm{Bu}$ düzenlemeler, finansal tabloları karşılaştırılabilirlik açısından olumlu yönde etkilemektedir. Ayrıca, TMS uygulamaları, sigorta sektöründe faaliyet gösteren şirketlerin finansal raporlamalarını ve finansal tablolarını dolayısıyla da muhasebe sisteminin kalitesini artırmaktadır.

$\mathrm{Bu}$ açıklamalar doğrultusunda çalışmanın iki temel amacı vardır. Bunlardan birincisi, TMS öncesi ve sonrası dönemde faaliyet gösteren sigorta şirketlerinin finansal tablolarından elde edilen finansal oranlar arasında farklılık olup olmadığını değerlendirmektir. Bu kapsamda, TMS uygulamalarının ülkemiz sigorta sektöründe faaliyet gösteren şirketlerin finansal yapısına muhtemel etkileri bu araştırma ile ortaya konulmuştur. TMS uygulanmalarının sigorta sektörü üzerindeki muhtemel etkileri; sermaye yeterliliği, aktif kalitesi, likidite, faaliyet ve karlılığa ilişkin finansal oranlar yardımıyla incelenmiştir. Çalışmanın ikinci amacı ise, TMS öncesi ve sonrası dönemde hesaplanan finansal oranların istatistiksel açıdan farklılık gösterip göstermediğini test etmektir. TMS öncesi ve sonrası dönemlerde sigorta şirketlerinin finansal durumunun değerlendirilmesi ve sigorta sektörünün ülke genelindeki durumunun ortaya konulması yatırımcılar için oldukça önemlidir. Bu kapsamda çalışma, yatırımcıların sigorta sektörüne yönelik geçmiş dönemlere ilişkin bilgi sahibi olması açısından önem taşımaktadır. 
Ayrıca çalışma, Türkiye örnekleminde bu konuda daha önceden yapılan bir çalışma olmadığı için önemlidir.

\subsection{Araştırmanın Örneklemi, Kısıtları ve Veri Seti}

TMS uygulamalarının sigorta sektörü üzerindeki etkilerini test etmek amacıyla yapılan çalışmanın örneklemini, Türk sigorta sektöründe 2003-2017 yılları arasında faaliyet gösteren ve hayat dışı branşta bulunan şirketler oluşturmaktadır. Çalışmanın en önemli kısıtı, sigorta sektörünün hayat branşında faaliyet gösteren sigorta şirketlerinin analize dâhil edilmemesidir. Bu durumun iki nedeni vardır. Birinci neden, hayat ve hayat dışı branşlarda faaliyet gösteren sigorta şirketlerinin faaliyet alanlarının farklı olması neticesinde, finansal analizlerinden elde edilen bulguların değişik olmasıdır. Diğer bir ifadeyle, iki farklı branşla ilgili yapılacak analiz yorumlamaları anlamsız olacaktır. İkinci neden ise, ülkemiz sigorta şirketlerinin büyük çoğunluğunun hayat dışı branşlarda faaliyet göstermesidir. Dolayısıyla, hayat dışı branşlarda faaliyet gösteren şirketlerin sigorta sektörünü temsil edecek sayıda olmasıdır. Hayat ve hayat dışı branşlarda faaliyet gösteren sigorta şirketlerinin finansal raporlarının farklı olması ve finansal oranların karşılaştırılmasında bütünlük sağlamak için çalışmanın kapsamı hayat dışı branşlarda faaliyet gösteren sigorta şirketleriyle sınırlandırılmıştır.

Çalışmanın diğer kısıtı ise araştırma analizine 2003 yılından önceki dönemlerin dâhil edilmemesidir. Bu durumun birinci nedeni ülkemiz sigorta sektöründe 2003 yılı öncesinde sağlıklı verilere ulaşılamamasıdır. Diğer bir neden ise ülkemizde 2003 yılından önce ciddi bir finansal krizin yaşanması ve bu durumun sağlıklı analiz yapmaya engel olmasıdır. Ayrıca analizde, TMS sonrası dönem olarak 2008-2017 yılları arasındaki uzun bir dönem kullanılmıştır. Bunun amacı; i) sigorta sektörünün güncel durumunu tespit etmek, ii) 2008 finansal krizinin etkisini analizlerde en aza indirmektir.

Ülkemiz sigorta sektöründe gerek sayı olarak, gerekse prim üretimi ve ödenen tazminat tutarı olarak hayat dışı branşlarda faaliyet gösteren sigorta şirketlerinin önemli bir yer tuttuğu bilinmektedir. Bu bağlamda, çalışma kapsamında sadece hayat dışı branşlarda faaliyet gösteren sigorta şirketlerinin analize dâhil edilmesinin Türkiye örnekleminde yeterli olduğu veya sigorta sektörünü temsil edecek sayıda olduğu söylenebilir. Ancak 2003-2017 yılları arasında ülkemizde, hayat dışı branşlarda faaliyet gösteren tüm şirketlerin verilerine ayrı ayrı ulaşmak mümkün değildir. $\mathrm{Bu}$ nedenle veriler "sektör ortalaması" dikkate alınarak sağlanmıştır. Bu şirketlere ait 2003-2017 dönemini kapsayan yıllık finansal tablo verileri, T.C. Hazine ve Maliye Bakanlığı Sigorta Denetleme Kurulu ile Türkiye Sigorta Birliği'nin (www.tsb.org.tr) resmi internet sitelerinden elde edilmiştir. 


\subsection{Araştırmanın Yöntemi ve Verilerin Analizi}

Çalışmanın temel amaçları kapsamında iki yöntem kullanılmıştır. Bunlar, finansal oran analizi ve Wilcoxon İşaretli Sıralar Testidir. Çalışmanın birinci amacı olan, TMS öncesi ve sonrası dönemlerde faaliyet gösteren sigorta şirketlerinin finansal tablolarından elde edilen finansal oranlar arasında farklılığ değerlendirmek üzere finansal analiz tekniklerinden oran analizi kullanılmıştır. Konuyla ilgili daha önce yapılan çalışmalar (Günkut, 2007; Yılmaz, 2010; Özuren, 2010; Süt, 2014; Ergin, 2015; Güleç, 2015; Çelik, 2017) incelendiğinde oran analizi yönteminin çok fazla kullanıldığı görülmektedir.

Analiz kapsamında öncelikle incelenen şirketlerin finansal durumları, bilanço ve gelir tablolarından elde edilen verilerle tablo ve grafik yardımıyla ortaya konulmuştur. Daha sonra ikinci bir analiz olarak sigorta şirketlerinin yıllar itibariyle karşılaştırmalı analizi yapılmıştır. Bunun için de sigorta şirketlerinin TMS öncesi ve sonrası dönemlerindeki finansal durumlarına ait verileri değerlendirilmiştir. Oran analizi yöntemi uygulanırken 2004 yılında Hazine Müsteşarlığı tarafından belirlenen ve yayınlanan Sigorta ve Reasürans Şirketlerinin Mali Bünyelerine ve Sermaye Yeterliliklerine İlişkin Genelgede yer alan finansal oranlar kullanılmıştır. Hesaplanan finansal oranlar, sigorta sektöründeki şirketlerin ortalama değerleriyle karşılaştırılmıştır. Buradaki amaç, TMS uygulamalarına geçtikten sonra sigorta şirketlerinin finansal yapısında yıllar itibariyle değişiklik olup olmadığını değerlendirmektir.

Çalışmanın ikinci amacı olan TMS öncesi ve sonrası dönemde sigorta şirketlerinin finansal tablolarından elde edilen finansal oranların, her iki dönem açısından aralarındaki ilişkiyi istatistiki açıdan belirleyebilmek için parametrik olmayan istatistiksel yöntemlerden Wilcoxon İşaretli Siralar Testi (Wilcoxon Signed Rank Test) kullanılmıştır. Bu yöntemin kullanılmasının temel nedeni analizde kullanılan dönem sayısının 30'un altında olması ve elde edilen verilerin normal dağ 1 lım göstermemesidir (Green ve Salkind, 2008). Bu analiz yöntemiyle, 20032017 yılları arasında sigorta sektöründe faaliyet gösteren şirketlerin verilerinden elde edilen finansal oranlar, TMS öncesi ve sonrası dönemler arasında anlamlı farklılık olup olmadığını ortaya koyabilmek amacıyla analiz edilmiştir. Analize dâhil edilen sigorta şirketlerinden elde edilen verilerden finansal oranların hesaplanması Microsoft Excel programı yardımıyla yapılmış olup, verilerin istatistiki analizinde de SPSS 20 İstatistik Paket Programı kullanılmıştır. Öte yandan çalışmada, TMS'nin Türk sigorta sektörü üzerindeki etkileri araştırılırken, sigorta şirketlerinin finansal oranlarından yararlanılmıştır. Diğer bir ifadeyle, TMS'nin uygulanmasıyla birlikte sigorta şirketlerinin finansal oranlarında herhangi bir değişiklik olup olmadığı test edilmiştir. Kısacası TMS'nin etkisi finansal oranlar yardımıyla test edilmeye çalışılmıştır.

\subsection{Araştırmada Kullanılan Finansal Oranlar}


Daha önce de belirtildiği üzere sigorta sektörü, Türk finans sisteminin önemli aktörlerinden birisidir. Ancak sigorta sektörü, faaliyet alanı veya finansal yapısı itibariyle diğer sektörlerden birçok yönden farklılaşmaktadır.

Söz konusu farklılıklar sigorta şirketinin muhasebe sistemlerine ve dolayısıyla da finansal tablolarına yansımaktadır. Diğer sektörlerdeki şirketlerin hesap planı ve finansal tablolarından farklılık arz eden sigorta şirketlerinin hesap planı ve mali tabloları Hazine Müsteşarlığınca 30.12.2004 tarihinde yayımlanan ve 01.01.2005 tarihinden itibaren yürürlüğe girmiş bulunan sigortacılık hesap planı ile daha da farklılaşmıştır. Bunun sonucunda, finansal tablolardan elde edilen finansal oranların hesaplanması ve yorumlanması da diğer işletmelere göre farklılık arz etmektedir (Dönmez, 2008, s. 105). Araştırmanın analizinde kullanılan ve sigorta sektörüne özgü olan finansal oranlar Tablo 1'de gösterilmiştir.

Tablo 1: Çalışmada Kullanılan Finansal Oranlar

\begin{tabular}{|c|c|}
\hline \multirow{4}{*}{$\begin{array}{c}\text { Sermaye } \\
\text { Yeterliliğine İlişkin } \\
\text { Oranlar }\end{array}$} & 1) Alınan Primler/Top. Özsermaye Oranı[APÖ] \\
\hline & 2) Top. Özsermaye/Varlık Toplamı Oranı[ÖVT] \\
\hline & 3) Top. Özsermaye/Teknik Karşıllklar (Net) Oranı [ÖTK] \\
\hline & 4) Sermaye Yeterlilik Oranı[SYO] \\
\hline \multirow{4}{*}{$\begin{array}{l}\text { Likiditeye ve Aktif } \\
\text { Kalitesine İlisikin } \\
\text { Oranlar }\end{array}$} & 5) Likit Varlıklar/Varlık Toplamı Oranı[LVO] \\
\hline & 6) Cari Oran[CO] \\
\hline & 7) Prim ve Reasürans Alacakları/Varlık Toplamı Oranı [PRA] \\
\hline & 8) Likidite Oranı[LO] \\
\hline \multirow{6}{*}{$\begin{array}{l}\text { Faaliyet Etkinliğine } \\
\text { İlişkin Oranlar }\end{array}$} & 9) Tazminat Tediye Oranı[TDO] \\
\hline & 10) Konservasyon Orani[KO] \\
\hline & 11) Teknik Karşıllık Oranı[TKKO] \\
\hline & 12) Reasürans Komisyon Oranı[RKO] \\
\hline & 13) Aracı Komisyon Oranı[AKO] \\
\hline & 14) Prim Artış Oranı[ARO] \\
\hline \multirow{6}{*}{$\begin{array}{l}\text { Kârlılık Durumuna } \\
\text { İlişkin Oranlar }\end{array}$} & 15) Hasar Prim Oranı[HPO] \\
\hline & 16) Aktif Karlık Oranı[AO] \\
\hline & 17) Özsermaye Karlık Oranı[ÖKO] \\
\hline & 18) Teknik Karlılık Oranı[TKO] \\
\hline & 19) Masraf Orani[MO] \\
\hline & 20) Bileşik Oran[BO] \\
\hline
\end{tabular}




\subsection{Sigortacılık Sektöründe Finansal Oran Analizi}

Sigorta sektörünün finansal analizinde kullanılan oranlar; sermaye yeterliliğine ilişkin oranlar, likiditeye ve aktif kalitesine ilişkin oranlar, faaliyet etkinliğine ilişkin oranlar ve karlılık durumuna ilişkin oranlar olmak üzere 4 kategoride ele alınabilir. Çalışmada, Türk sigorta sektöründe 2003-2017 yılları arasında hayat dışı branşta faaliyet gösteren sigorta şirketlerinin verilerinden yararlanılmıştır. Söz konusu döneme ilişkin finansal oran analizi bulguları ve yorumları aşağıda sırasıyla açıklanmıştır.

\subsubsection{Sermaye Yeterliliğine İlişkin Oranların Bulguları}

Sermaye yeterliliği ile ilgili finansal oranlar, sigorta şirketlerinin, müşterilerine veya sigortalılara karşı olan sorumluluklarını yerine getirip getirememe gücünü ölçmek ve bu gücünde değişiklik olup olmadığı hakkında bilgi sahibi olmak için hesaplanmaktadır. Bu oranlar kendi içinde 4 gruba ayrılmaktadır. Bunlar; Alınan Primler/Toplam Özsermaye, Toplam Özsermaye/Varlık Toplamı, Toplam Özsermaye/Teknik Karşılıklar(Net) ve Sermaye Yeterlilik Oranlarıdır. Sermaye yeterliliğine ilişkin finansal oran analizi bulguları TMS öncesi ve TMS sonrası olarak Tablo 2'de gösterilmiştir.

Tablo 2: Sermaye Yeterliliğine İlişkin Oranlar

\begin{tabular}{|c|c|c|c|c|}
\hline & $\begin{array}{c}\text { Alınan Primler / } \\
\text { Top. Özsermaye } \\
\text { Oranı (APÖ) }\end{array}$ & $\begin{array}{c}\text { Top. Özsermaye / } \\
\text { Varlık Toplamı } \\
\text { (ÖVT) }\end{array}$ & $\begin{array}{c}\text { Top. Özsermaye / } \\
\text { Teknik Karşılık } \\
\text { Oranı (ÖTK) }\end{array}$ & $\begin{array}{c}\text { Sermaye } \\
\text { Yeterlilik } \\
\text { Oranı(SYO) }\end{array}$ \\
\hline $\begin{array}{c}\text { TMS Öncesi } \\
\text { Ortalama } \\
(\mathbf{2 0 0 3 - 2 0 0 7 )}\end{array}$ & 2,346 & 0,428 & 1,077 & 2,106 \\
\hline $\begin{array}{c}\text { TMS Sonrası } \\
\text { Ortalama } \\
\text { (2008-2017) }\end{array}$ & 2,406 & 0,317 & 0,600 & 1,119 \\
\hline
\end{tabular}

Sermaye yeterliliğine ilişkin hesaplanan finansal oran analizi bulgularının zaman içerisindeki değişimleri Grafik 1'de gösterilmiştir.

Tablo 2 ve Grafik 1'in ortaya koyduğu üzere, analiz kapsamında incelenen sigorta şirketlerinde, alınan primlerin özsermaye içeresindeki payı ile şirketin yükümlülüklerini yerine getirebilme veya mali yapısının gücünü gösteren APÖ’nün, 2003-2017 yılları arasında sigorta sektörü ortalamasının, kritik değer olan 4'ün altında olduğu tespit edilmiştir. Sektör ortalamasının yıllar itibariyle gelişimi incelendiğinde en yüksek oranın 2003, 2004 ve 2016 yıllarına; en düşük oranın ise 2005, 2007 ve 2009 yıllarına ait olduğu görülmektedir. Ayrıca APÖ’nün sektör ortalamalarının 2003-2007 yılları arasında düşme eğiliminde; 2008-2017 yılları arasında ise yükselme eğiliminde olduğu anlaşılmaktadır. 
TMS uygulamalarının etkisi incelendiğinde ise bu oranın sektör ortalamasının TMS öncesi 2,346; TMS sonrasında ise 2,406 olduğu hesaplanmıştır. Bu sonuç, TMS'yle birlikte APÖ'nün az da olsa yükseldiğini ve TMS uygulamalarıyla birlikte sektörde faaliyet gösteren şirketlerin sigortalılara karşı yükümlülüklerini yerine getirebilme gücünün veya mali yapılarının az da olsa güçlendiğini ortaya koymaktadir.

Sigorta şirketinin sermaye yapısının güçlü olup olmadığını ve uzun vadede borçlarını ödeme gücünü gösteren ÖVT'nin yıllar itibariyle gelişimi incelendiğinde, sigorta şirketlerinin sektör ortalamasının en yüksek olduğu yıllar 2005, 2006 ve 2007 yılları iken; en düşük oranının ise 2004, 2015 ve 2016 y1llarına ait olduğu görülmektedir. Grafik 1'den de görüldüğü üzere sigorta şirketlerinin sektör ortalamalarının, 2003-2017 yılları arasındaki değişiminin durağan olduğu anlaşılmaktadır. TMS uygulamalarının etkisi incelendiğinde bu oranın sektör ortalamasının TMS öncesi 0,428 ; TMS sonrasında ise 0,317 olduğu hesaplanmıştır. Bu sonuç, TMS'yle birlikte ÖVT'nin azda olsa düştüğünü ve şirketlerin mali yapılarının zayıfladığını göstermektedir. Ayrıca bu sonuç mali yapının güçlülüğünü gösteren diğer bir oran olan APÖ’nun sonuçlarıyla ters yöndedir.

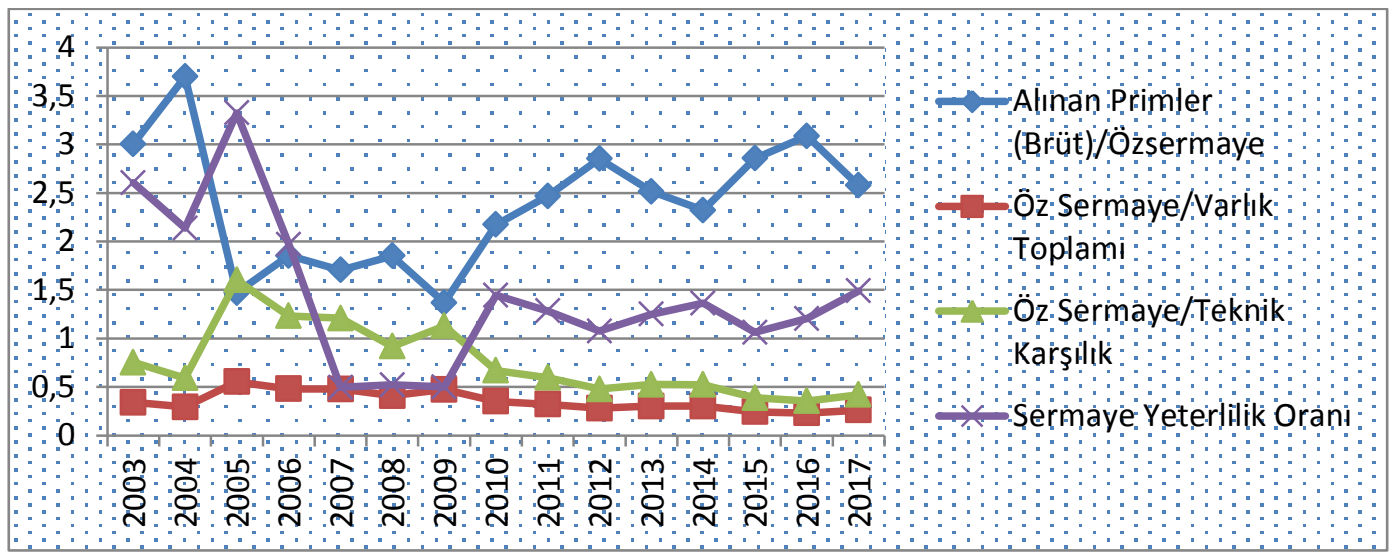

\section{Grafik 1: Sermaye Yeterliliğine İlişkin Oranlar}

Sigorta şirketlerinin teknik karşılıklarının özsermayeden karşılanma seviyesini ölçen ÖTK'nın yıllar itibariyle gelişimi incelendiğinde, sigorta şirketlerinin sektör ortalamalarında en yüksek oranın 2005, 2006 ve 2007 yıllarına; en düşük oranın ise 2017, 2016 ve 2015 yıllarına ait olduğu görülmektedir. Tablodan da görülebildiği üzere ÖTK'nın, 2004-2008 yılları arasında yükselme eğiliminde olduğu; 2009-2017 yılları arasında ise durağan olduğu anlaşılmaktadır. TMS uygulamalarının etkisi incelendiğinde; ÖTK'nın sektör ortalamasının TMS öncesi 1,077; TMS sonrasında ise 0,60 olduğu hesaplanmıştır. Bu sonuç, TMS'yle birlikte ÖTK'nın önemli derecede düştüğünü göstermektedir. Ayrıca TMS ile birlikte sigorta sektöründeki şirketlerin genel olarak teknik karşılıklarının 
özsermayeden karşılanma seviyesinin azaldığı ve dolayısıyla sektörün özsermeye gücünün de TMS ile birlikte zayıfladığı söylenebilir.

Sigorta sektöründeki şirketlerin özsermeye gücünün en önemli göstergesi olan SYO'nun yıllar itibariyle gelişimi incelenecek olursa, sigorta şirketlerinin sektör ortalamalarının en yüksek olduğu dönemlerin 2003, 2004 ve 2005; en düşük olduğu dönemlerin ise 2007, 2008 ve 2009 yılları olduğu görülmektedir. Tablonun ortaya koyduğu üzere, SYO'da 2003-2008 yılları arasında hızlı bir azalış yaşanırken, 2009-2017 yılları arasında önemli bir değişiklik olmamıştır. TMS uygulamalarının etkisi incelendiğinde ise bu oranın sektör ortalamasının TMS öncesi 2,106; TMS sonrasında 1,119 olduğu bulunmuştur. Bu sonuç, TMS'yle birlikte SYO'nun oranının önemli derecede düştüğünü göstermektedir. Ayrıca TMS ile birlikte sigorta sektöründeki şirketlerin genel olarak sermeye gücünün veya mali yapısının azaldığı söylenebilir.

\subsubsection{Aktif Kalitesi ve Likiditeye İlişkin Oranların Bulguları}

Sigorta sektöründe likidite oranları şirketlerin kısa vadeli borçlarını zamanında ödeyebilme veya yükümlülüklerini zamanında yerine getirebilme gücünü ifade eder. Ayrıca bu oranlar şirketlerin likidite durumunu, vadesi gelen borçlarını zamanında ödeyebilme gücünü ve faaliyetlerine devam edebilme potansiyelini gösterir. Söz konusu orandaki herhangi bir yükseliş, şirket likit varlıklarının arttığ1 ve bunun sonucunda da borçlarını ödeyebilme gücünde artış olduğu şeklinde yorumlanabilir (Süt, 2014, s. 36 ). Aktif kalitesi ve likiditeye ilişkin finansal oran analizi bulguları TMS öncesi ve TMS sonrası ortalamalar olarak Tablo 3 'de zaman içerisindeki değiş̧imleri Grafik 2'de gösterilmişstir.

Tablo 3: Aktif Kalitesi ve Likiditeye İlişkin Oranlar

\begin{tabular}{|c|c|c|c|c|}
\hline & $\begin{array}{c}\text { Likit Var. / } \\
\text { Varlık Toplamı } \\
\text { (LVO) }\end{array}$ & $\begin{array}{c}\text { Cari Oran } \\
\text { (CO) }\end{array}$ & $\begin{array}{c}\text { Prim ve Reas. Al./ } \\
\text { Top. Öz Sermaye } \\
\text { (PRA) }\end{array}$ & $\begin{array}{c}\text { Likidite Oranı } \\
\text { (LO) }\end{array}$ \\
\hline $\begin{array}{c}\text { TMS Öncesi } \\
\text { Ortalama } \\
(\mathbf{2 0 0 3 - 2 0 0 7 )}\end{array}$ & 0,325 & 1,150 & 0,696 & 0,555 \\
\hline $\begin{array}{c}\text { TMS Sonrası } \\
\text { Ortalama } \\
(\mathbf{2 0 0 8 - 2 0 1 7 )}\end{array}$ & 0,523 & 1,195 & 0,511 & 0,742 \\
\hline
\end{tabular}

Tablo 3 ve Grafik 2'nin ortaya koyduğu üzere analiz kapsamında incelenen sigorta şirketlerinin aktif kalitesi ve likiditeye ilişkin oranlarından biri olan LVO'nun sektör ortalamasının en düşük olduğu yıllar 2004, 2005 ve 2006 iken en yüksek olduğu yıllar ise 2014, 2016 ve 2017'dir. LVO, 2003-2008 yılları arasında durağan bir gelişim gösterirken, 2009-2017 yılları arasında az da olsa artış trendindedir. TMS uygulamalarının etkisi incelendiğinde LVO'nun sektör 
ortalamasının TMS öncesi 0,325 ; TMS sonrasında ise 0,523 olduğu tespit edilmiştir. Bu sonuç, TMS'yle birlikte LVO'nun yükseldiğini göstermektedir. Diğer bir ifadeyle LVO'nun sektör ortalamasının TMS sonrası yükselmesi, sigorta sektörünün yükümlülüklerini yerine getirebilme gücünün arttığı ve likidite durumunun güçlendiği şeklinde yorumlanabilir.

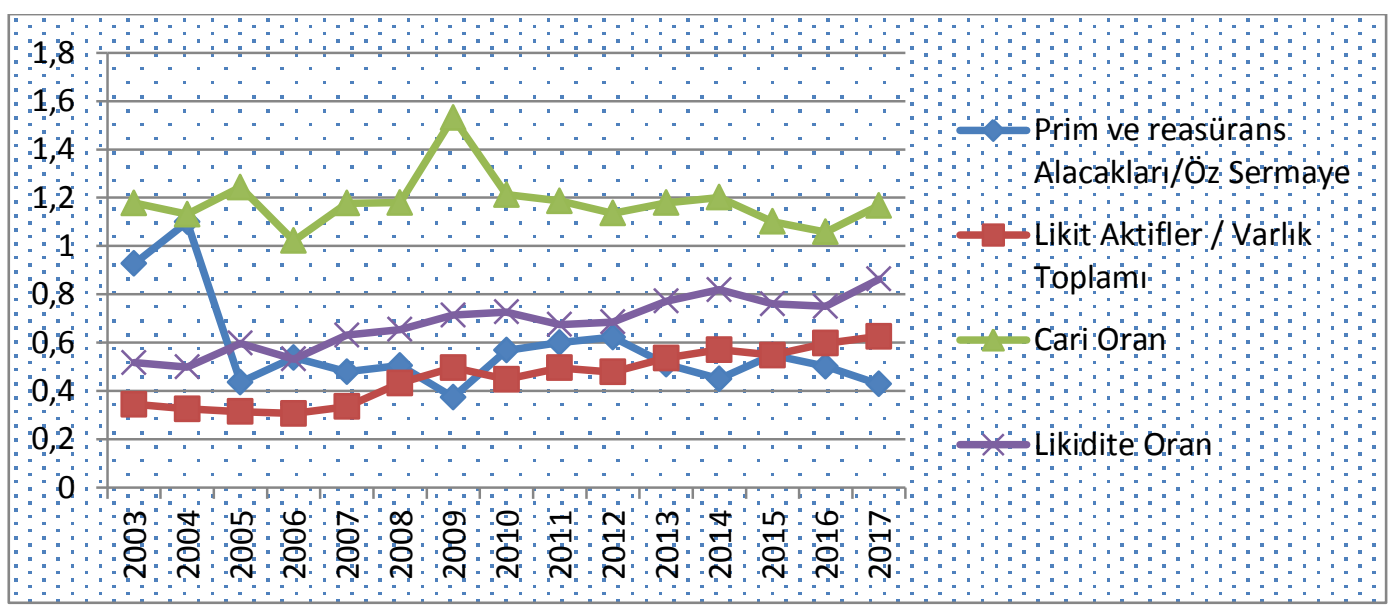

\section{Grafik 2: Aktif Kalitesi ve Likiditeye İlişkin Oranlar}

Sigorta şirketlerinin kısa vadeli borçlarını veya yükümlülüklerini karşılayabilme gücünü gösteren cari oranının yıllar itibariyle gelişimi incelendiğinde, sigorta şirketlerinin sektör ortalamasının en yüksek olduğu yılların 2005, 2014 ve 2009; en düşük olduğu yılların ise 2006, 2015 ve 2016 olduğu görülmüştür. Ayrıca CO’nun, genel olarak tüm yıllarda kritik değer olan birin üzerinde olduğu tespit edilmiştir. CO'da, 2008-2009 yılları arasında önemli bir artış olduğu, diğer yıllarda ise değişiklik olmadığı söylenebilir. TMS uygulamalarının etkisi incelendiğinde, CO'nun sektör ortalamasının TMS öncesi 1,150; TMS sonrasında ise 1,195 olduğu bulunmuştur. Bu sonuç, TMS'yle birlikte CO'nun az da olsa yükseldiğini göstermektedir. Diğer bir ifadeyle TMS ile birlikte sigorta sektörünün nakit gücü az da olsa artmış ve sektörün kısa vadeli yükümlülüklerini yerine getirebilme gücü yükselmiştir.

Prim ve reasürans alacaklarının varlık toplamı içindeki payını gösteren Prim ve Reasürans Alacakları/Varlık Toplamı oranının yıllar itibariyle gelişimi incelendiğinde, sigorta şirketlerinin sektör ortalamalarında en yüksek oranın 2003, 2004 ve 2012 yılında; en düşük oranın ise 2005, 2009 ve 2017 y1lında olduğu tespit edilmiştir. Tablodan görülebildiği üzere PRA'da, 2003-2017 yılları arasında önemli bir değişiklik olmamıştır. TMS uygulamalarının etkisi incelendiğinde, bu oranın sektör ortalamasının TMS öncesi 0,696; TMS sonrasında ise 0,511 olduğu hesaplanmıştır. PRA'nın yükssek olması şirketlerin likiditesinin zayıf olduğunun göstergesidir. Bu sonuç, TMS'yle birlikte PRA'nın az da olsa düştüğünü ve bu 
nedenle de sektördeki şirketlerin likiditesinin TMS öncesine göre güçlü olduğunu ifade etmektedir.

Sigorta şirketlerinin kısa vadeli borçlarını karşılayabilme gücünü gösteren Likidite Oranının yıllar itibariyle gelişimi incelendiğinde, sigorta şirketlerinin sektör ortalamalarında en yüksek oranın 2014, 2015 ve 2017 yıllarına; en düşük oranın ise 2003, 2004 ve 2006 yıllarına ait olduğu görülmektedir. Ayrıca LO'nun, genel olarak tüm yıllarda kritik değer olan birin altında olduğu tespit edilmiştir. Tablodan da görüldüğü üzere bu oranda, 2003-2005 yılları arasında önemli bir düşüş, diğer yıllarda ise yükselme olduğu görünmektedir. TMS uygulamalarının etkisi incelendiğinde LO'nun sektör ortalamasının TMS öncesi 0,555; TMS sonrasında ise 0,742 olduğu bulunmuştur. Bu sonuç, TMS'yle birlikte LO'nun az da olsa yükseldiği, buna bağlı olarak da sigorta şirketlerinin nakit gücünün arttığ1 şeklinde yorumlanabilir. Bulunan bu sonuç, sigorta şirketleriyle ilgili likiditeye ilişkin diğer oranlarla aynı yöndedir.

\subsubsection{Faaliyet Etkinliğine İlişkin Oranların Bulguları}

Faaliyet oranları, sigorta sektöründe şirketlerin faaliyetlerine bağlı olarak dönen varlıkların durumunu göstermektedir. Faaliyet oranlarına ilişkin finansal oran analiz bulguları TMS öncesi ve TMS sonrası ortalamaları olarak Tablo 4'de, bu bulguların zaman içerisinde göstermiş olduğu değişim Grafik 3'de gösterilmiştir.

Tablo 4: Faaliyet Oranları

\begin{tabular}{|c|c|c|c|c|c|c|}
\hline & $\begin{array}{c}\text { Tazminat } \\
\text { Tediye (Prim) } \\
\text { Oranı }\end{array}$ & $\begin{array}{c}\text { Konservas } \\
\text { yon Oranı }\end{array}$ & $\begin{array}{c}\text { Teknik } \\
\text { Karşılı } \\
\text { Oranı }\end{array}$ & $\begin{array}{c}\text { Reasürans } \\
\text { Komisyon } \\
\text { Oranı }\end{array}$ & $\begin{array}{c}\text { Aracı } \\
\text { Komisyon } \\
\text { Oranı }\end{array}$ & $\begin{array}{c}\text { Prim Artış } \\
\text { Oranı }\end{array}$ \\
\hline $\begin{array}{c}\text { TMS Öncesi } \\
\text { Ortalama } \\
\text { (2003-2007) }\end{array}$ & 0,652 & 0,633 & 0,033 & 0,199 & 0,145 & 0,266 \\
\hline $\begin{array}{c}\text { TMS Sonrası } \\
\text { Ortalama } \\
(\mathbf{2 0 0 8 - 2 0 1 7 )}\end{array}$ & 0,750 & 0,790 & 0,020 & 0,181 & 0,153 & 0,176 \\
\hline
\end{tabular}

Sigorta şirketlerinin sigorta faaliyetleri kapsamında üstlendikleri gerçek riski ölçmek için hesaplanan oran olan konservasyon oranının yıllar itibariyle gelişimi Tablo 4 ve Grafik 3'de gösterilmiştir. Buna göre, KO'nun sektör ortalamasının en yüksek olduğu yıllar 2012 ve 2016 iken; en düşük olduğu y1llar ise 2003 ve 2004 'tür. Ayrıca KO'nun 2008 yılından itibaren yükselme trendinde olduğu da anlaşılmaktadır. TMS uygulamalarının $\mathrm{KO}$ üzerinde etkisi incelendiğinde bu oranın sektör ortalamasının TMS öncesi 0,633 ; TMS sonrasında ise 0,790 olduğu belirlenmiştir. Bu sonuç, TMS uygulamalarıyla birlikte KO'nun yükseldiğini ve sigorta şirketlerinin muhtemel riskleri daha fazla üstlendiklerini göstermektedir. Ayrıca bu sonucun sigorta şirketlerinin sürekliliği ve karlılığ i için de önemli bir durum olduğu unutulmamalıdır. 


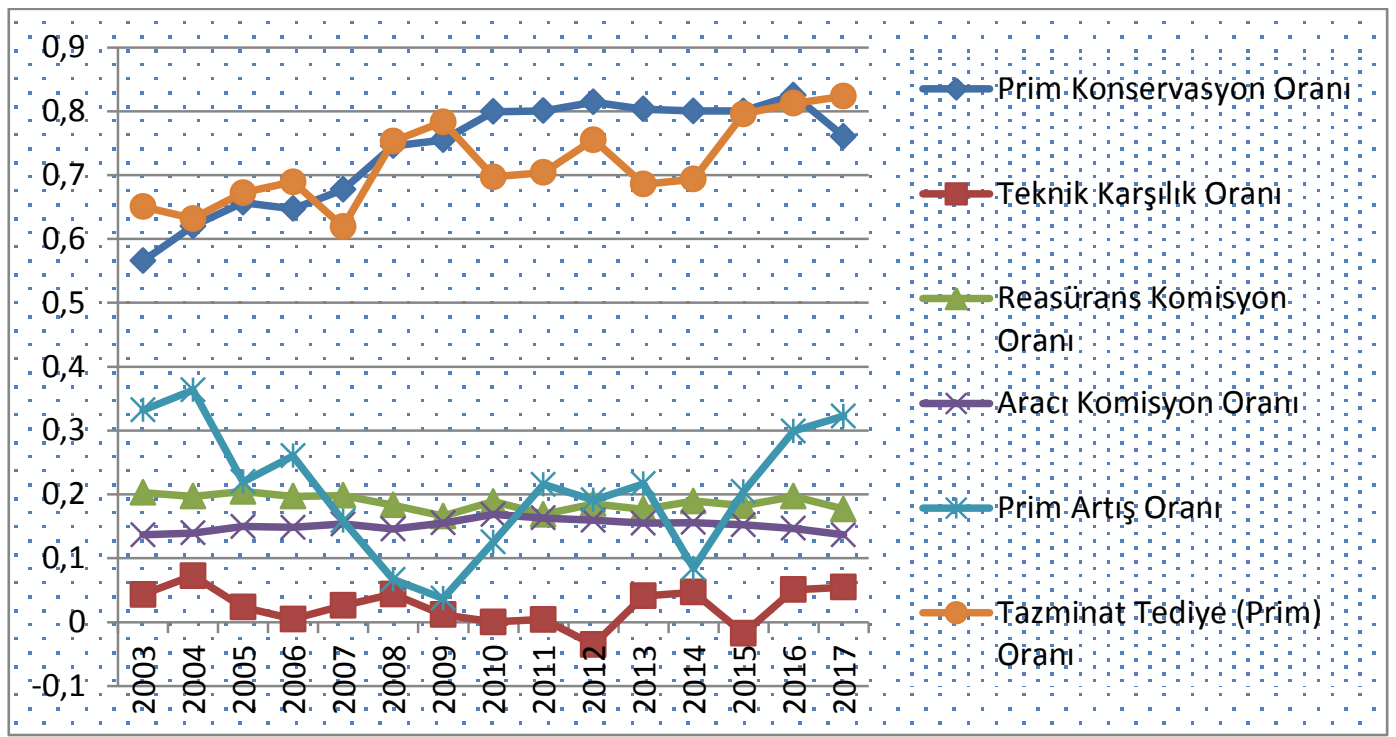

\section{Grafik 3: Faaliyet Oranları}

Teknik karşılık oranının yıllar itibariyle gelişimi incelendiğinde, sigorta şirketlerinde TKKO'nun sektör ortalamasının en yüksek olduğu yıllar 2004 ve 2017 iken; en düșük olduğu yıllar 2012 ve 2015'tir. Grafik 3'de görüldüğü üzere TKKO'nun, 2003-2017 yılları arasında durağan bir trendde, 2012 ve 2015 yıllarında ise negatif değerde olduğu anlaşılmaktadır. TMS uygulamalarının etkisi incelendiğinde, bu oranın sektör ortalamasının TMS öncesi 0,033; TMS sonrasında ise 0,020 olduğu tespit edilmiştir. Bu sonuç, TMS'yle birlikte TKKO'nun azda olsa düştüğünü göstermektedir.

Teknik karşılıkların varlık veya kaynak toplamı içindeki payını gösteren TKKO'nun yüksek olması, sigorta şirketinin faaliyet hacmiyle bağlantılı olarak ihtiyatlı davrandığının göstergesidir. Bu kapsamda, analiz kapsamında incelenen sigorta şirketlerinin TMS uygulamalarıyla birlikte daha az ihtiyatlı davrandıkları söylenebilir.

Reasüröre devredilen prim miktarı üzerinden reasürörün sedan şirkete ödeyeceği komisyon tutarını gösteren reasürans komisyon oranının sektör ortalamasının en yüksek olduğu yılın 2007, en düşük olduğu yılların ise 2004 ve 2006 olduğu tespit edilmiștir. Oranın 2003-2017 y1llarında sabit bir trendde olduğu anlaşılmaktadır. TMS uygulamalarının etkisi incelendiğinde, RKO'nun sektör ortalamasının TMS öncesi 0,199; TMS sonrasında ise 0,181 olduğu tespit edilmiştir. Bu sonuç, TMS'yle birlikte RKO’nun azda olsa düştüğünü göstermektedir.

Sigorta şirketlerinin, acente veya brokerlar aracılığıyla topladıkları prim üretimlerini veya gelirlerini gösteren aracı komisyon oranının sektör ortalamasının en yüksek olduğu yıllar 2010 ve 2011 iken; en düşük olduğu yıllar 2003 ve 2014'tür. Ayrıca AKO'nun, 2003-2007 yılları arasında gelişiminin durağan 
olduğu, 2008 ve 2017 ylllarında ise azda olsa yükselme trendinde olduğu görülmektedir. TMS uygulamalarının AKO üzerindeki etkisi incelendiğinde, AKO'nun sektör ortalamasının TMS öncesi 0,145 ; TMS sonrasında ise 0,153 olduğu tespit edilmiştir. $\mathrm{Bu}$ sonuç, TMS'yle birlikte AKO'nun azda olsa yükseldiği, başka bir ifade ile sigorta şirketlerinin aracilara daha fazla komisyon ödediği şeklinde yorumlanabilir.

Analiz kapsamında incelenen sigorta şirketlerinin prim artış oranının sektör ortalamasının en yüksek olduğu yıllar 2003 ve 2004 iken; en düşük olduğu yıllar 2008 ve 2009'dur. Ayrica ARO'nun, 2003-2017 yılları arasında dalgalı bir trendde olduğu anlaşılmaktadır. TMS uygulamalarının etkisi incelendiğinde, bu oranın sektör ortalamasının TMS öncesi 0,266 ; TMS sonrasında ise 0,176 olduğu tespit edilmiştir. Bu sonuç, TMS'yle birlikte ARO'nun düştüğünü göstermektedir. Ayrıca bu değerler göz önüne alınarak sigorta şirketlerinin ana gelir kaynağı olan primlerin TMS uygulamalarıyla birlikte artmadığı ve TMS'nin sigorta sektörünün gelirleri üzerinde olumlu bir etki yapmadığı söylenebilir.

Sigorta şirketinin hasarların meydana gelmesi durumunda sigortalılara ödedikleri tazminat tutarını gösteren tazminat tediye oranının en yüksek olduğu yıllar 2016 ve 2017 iken; en düşük olduğu yıllar 2007 ve 2004'tür. Ayrıca TDO'nun, genel olarak tüm yıllarda kritik değer olan \%60-\%80 arasında olduğu tespit edilmiştir. Grafik 3'de görüldüğü üzere TDO'nun, 2003-2017 yılları arasında yükseliş trendinde olduğu anlaşılmaktadır. TMS uygulamalarının etkisi incelendiğinde, bu oranın sektör ortalamasının TMS öncesi 0,652 ; TMS sonrasında ise 0,750 olduğu tespit edilmiştir. Bu sonuç, TMS'yle birlikte TDO'nun yükseldiği ve sigorta şirketlerinin muhtemel hasarları ödeme gücünün arttığı şeklinde yorumlanabilir. $\mathrm{Bu}$ durum TMS uygulamalarıyla birlikte sigorta şirketlerinin faaliyetlerinin veya ödeme gücünün arttığının göstergesidir.

\subsubsection{Karlılık Durumuna İlişkin Oranların Bulguları}

Sigorta sektöründe karlılık oranları sigorta şirketlerinin cari dönem içinde elde etmiş oldukları karı yorumlamak amacıyla kullanılmaktadır. Karlılık oranlarına ait finansal oran analizi bulguları Tablo 5'de gösterilmiştir.

Tablo 5: Karlılık Oranları

\begin{tabular}{|l|c|c|c|c|c|c|}
\hline & $\begin{array}{c}\text { Masraf } \\
\text { Oranı }\end{array}$ & $\begin{array}{c}\text { Birleşik } \\
\text { Oran }\end{array}$ & $\begin{array}{c}\text { Teknik } \\
\text { Karlıı } \\
\text { Oranı }\end{array}$ & $\begin{array}{c}\text { Hasar/ } \\
\text { Prim } \\
\text { Oranı }\end{array}$ & $\begin{array}{c}\text { Özsermaye } \\
\text { Karlıı } \\
\text { Oranı }\end{array}$ & $\begin{array}{c}\text { Aktif } \\
\text { Karlık } \\
\text { Oranı }\end{array}$ \\
\hline $\begin{array}{l}\text { TMS Öncesi } \\
\text { Ortalama } \\
(\mathbf{2 0 0 3 - 2 0 0 7 )}\end{array}$ & $\mathbf{0 , 2 1 7}$ & $\mathbf{0 , 8 6 7}$ & $\mathbf{0 , 0 3 3}$ & $\mathbf{0 , 6 5 8}$ & $\mathbf{0 , 1 4 1}$ & $\mathbf{0 , 0 5 0}$ \\
\hline
\end{tabular}


Tablo 5: Karlılık Oranları (Devam)

\begin{tabular}{|l|c|c|c|c|c|c|}
\hline $\begin{array}{l}\text { TMS Sonrası } \\
\text { Ortalama } \\
(2008-2017)\end{array}$ & $\mathbf{0 , 2 3 6}$ & $\mathbf{0 , 9 6 9}$ & $\mathbf{0 , 0 2 0}$ & $\mathbf{0 , 6 9 7}$ & $\mathbf{0 , 0 6 7}$ & $\mathbf{0 , 0 1 8}$ \\
\hline
\end{tabular}

Karlılık oranlarına ilişkin finansal analiz bulgularının zaman içerisinde göstermiş olduğu değişim Grafik 4'de gösterilmiştir.

Tablo 5 ve Grafik 4 genel olarak değerlendirildiğinde, hasar prim oranının yıllar itibariyle gelişim bakımından sigorta şirketlerinin sektör ortalamasının en yüksek olduğu yıllar 2015 ve 2017 iken; en düşük olduğu yıllar 2004 ve 2009'dur. Ayrıca HPO değerinin, 2003-2007 yılları arasında dalgalı bir trendde olduğu, 2008 ve 2017 yıllarında azda olsa yükselme trendinde olduğu anlaşılmaktadır. TMS uygulamalarının etkisi incelendiğinde, HPO'nun sektör ortalamasının TMS öncesi 0,658; TMS sonrasında ise 0,697 olup, bulunan değerin her iki dönemde de çok fazla değişmediği veya azda olsa yükseldiği belirlenmiştir. Diğer bir ifadeyle, sigorta şirketleri için temel performans göstergesi olan ve şirketlerin topladıkları primlerin ne kadarlık kısmının muhtemel hasarları karşılayabilecek durumda olduğunu gösteren HPO'nun, TMS uygulamalarıyla birlikte çok fazla değişmediği söylenebilir. HPO'nun değişmemesi durumu, şirketlerin her iki analiz döneminde de karlılığını olumsuz yönde etkileyecek fazla hasar ödemesinin olmadığı şeklinde yorumlanabilir.

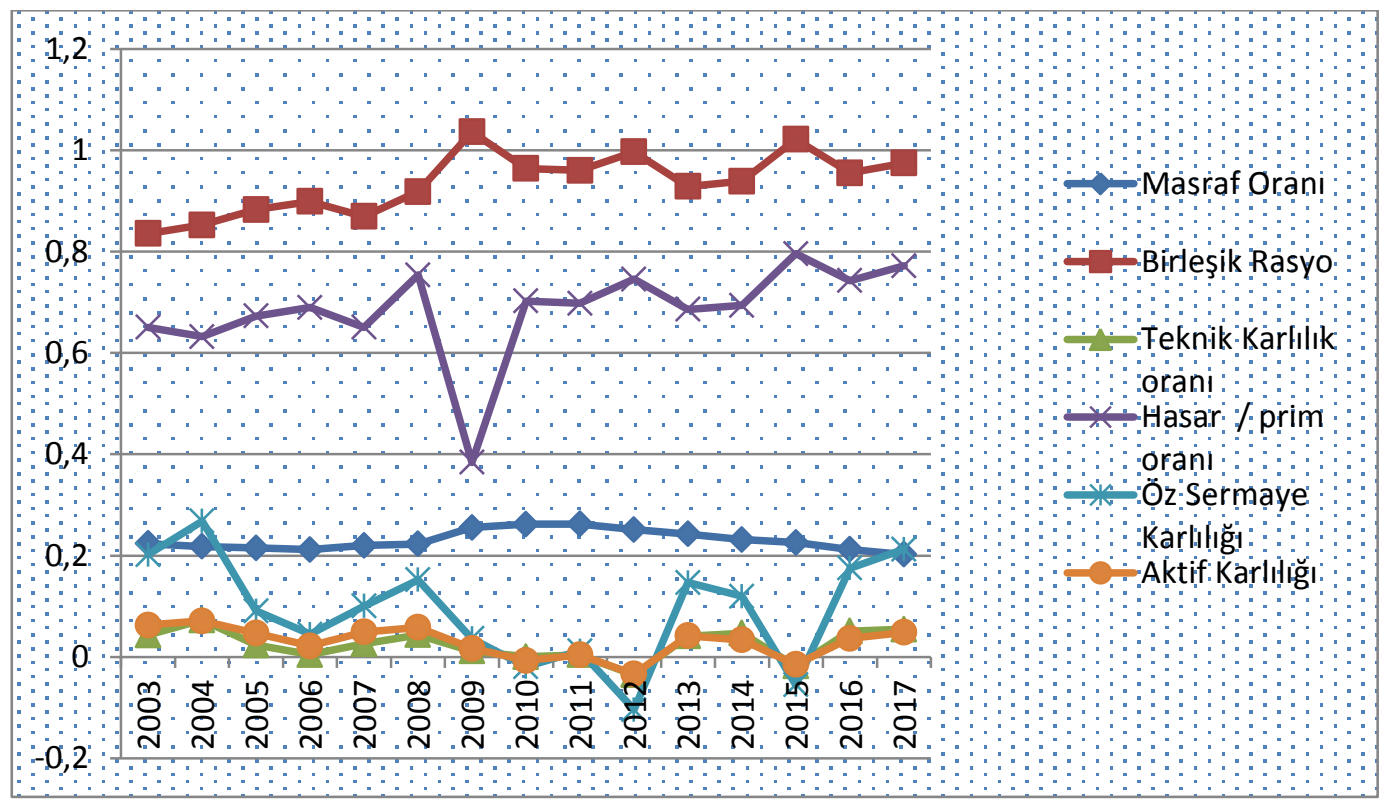

Grafik 4: Karlılık Oranları 
Sigorta şirketlerinde prim gelirleri ile giderler arasındaki ilişkiyi gösteren masraf oranı yıllar itibariyle incelendiğinde, sektör ortalamasının en yüksek olduğu yıl 2010 iken; en düşük olduğu yıl 2017'dir. Grafik 4'de görüldüğü üzere MO'nun, 2003-2017 yılları arasında durağan bir trendde olduğu anlaşılmaktadır. TMS uygulamalarının etkisi incelendiğinde, bu oranın sektör ortalamasının TMS öncesi 0,217; TMS sonrasında ise 0,236 olduğu tespit edilmiştir. Bu sonuç, TMS'yle birlikte masraf oranının çok az bir yükseliş gösterdiğini, bu yükselişin ihmal edilebilecek kadar olduğunu ortaya koymaktadır. Ayrıca bu sonuca bakılarak sigorta şirketleri tarafindan toplanan prim gelirlerinin giderlerle olan payını veya prim gelirlerinin hasarları karşılama potansiyelinde de, TMS öncesi ve sonrası dönemler bakımından herhangi bir değişiklik olmadığı şeklinde yorumlanabilir.

Birleşik oranın yıllar itibariyle gelişimi incelendiğinde, sigorta şirketlerinin sektör ortalamasının en yüksek olduğu yılların 2009 ve 2015; en düşük olduğu yılların ise 2003 ve 2004 olduğu görülmektedir. Grafik 4'de izlenebildiği üzere bu oran, 2003-2017 yılları arasında az da olsa yükseliş trendi göstermiştir. TMS uygulamalarının etkisi incelendiğinde, bu oranın sektör ortalamasının TMS öncesi 0,867; TMS sonrasında ise 0,969 olduğu tespit edilmiştir. Bu sonuç, TMS ile birlikte BO'nun yükseldiğini ortaya koymaktadır. Toplanan prim gelirleri için ne kadarlık gider yapıldığını gösteren BO'nun düşük olması gerekliliğinden hareketle, TMS uygulamalarıyla birlikte oranın yükselmesi, şirketlerin gelir sağlamak için daha fazla gider yaptığ 1 ve bu sonucun da istenilen bir durum olmadığ 1 şeklinde yorumlanabilir.

Teknik karlılık oranının sigorta şirketlerinin sektör ortalamasının en yüksek olduğu yıllar 2016 ve 2017 iken; en düşük olduğu yıllar 2012 ve 2015'dir. Grafik 4'de görüldüğü üzere bu oranın, 2003-2017 y1lları arasında durağan bir trendde olduğu anlaşılmaktadır. TMS uygulamalarının etkisi incelendiğinde, TKO'nun sektör ortalamasının TMS öncesi 0,033 ; TMS sonrasında ise 0,020 olduğu tespit edilmiştir. $\mathrm{Bu}$ sonuç, TMS'yle birlikte TKO'nun azda olsa düştüğünü göstermektedir.

Özsermaye karlılık oranının sigorta şirketlerinin sektör ortalamasının yüksek olduğu yıllar 2004 ve 2017 iken; en düşük olduğu yıllar 2012 ve 2015'dir. Grafik 4'de görüldüğü üzere bu oranın, 2003-2017 yılları arasında dalgalı bir trendde olduğu anlaşılmaktadır. TMS uygulamalarının etkisi incelendiğinde, ÖKO'nun sektör ortalamasının TMS öncesi 0,141 ; TMS sonrasında ise 0,067 olduğu tespit edilmiştir. Bu sonuç, TMS ile birlikte ÖKO'da önemli derecede düşüş olduğunu göstermektedir.

Aktif karlılık oranının yıllar itibariyle gelişimi incelendiğinde, sigorta şirketlerinin sektör ortalamasının en yüksek olduğu yıllar 2003 ve 2004 yılları iken; en düşük olduğu y1llar 2012 ve 2015'dir. Grafik 4'de görüldüğü üzere bu oranın, 20032017 yılları arasında dalgalı bir trendde olduğu anlaşılmaktadır. TMS uygulamalarının etkisi incelendiğinde, AO’nun sektör ortalamasının TMS öncesi 
0,050; TMS sonrasında ise 0,018 olduğu tespit edilmiştir. Bu sonuç, TMS'yle birlikte AO'nun düştügünü göstermektedir. Diğer bir ifadeyle, sigorta sektöründeki şirketlerin karlılığında TMS'nin olumlu yönde etkisinin olmadığ söylenebilir.

\subsection{Wilcoxon İşaretli Sıralar Testi Analizi}

\subsubsection{Tanımlayıcı (Açıklayıcı) İstatistikler}

TMS'nin sigorta sektörü üzerindeki etkilerini test etmek amacıyla araştırmanın analizinde kullanılan ve sigorta şirketlerinin 2003-2017 dönemine ait finansal oranlara ilişkin tanımlayıcı istatistiki bilgiler Tablo 6'da sunulmuştur.

Tablo 6: Tanımlayıcı İstatistik Sonuçları

\begin{tabular}{|c|c|c|c|c|c|c|c|c|}
\hline & \multicolumn{2}{|c|}{ Ortalama } & \multicolumn{2}{|c|}{ Minimum } & \multicolumn{2}{|c|}{ Maximum } & \multicolumn{2}{|c|}{ Std. Sapma } \\
\hline Finansal Oranlar & $\begin{array}{c}\text { TMS } \\
\text { Öncesi }\end{array}$ & $\begin{array}{c}\text { TMS } \\
\text { Sonrası }\end{array}$ & $\begin{array}{c}\text { TMS } \\
\text { Öncesi }\end{array}$ & $\begin{array}{c}\text { TMS } \\
\text { Sonrası }\end{array}$ & $\begin{array}{l}\text { TMS } \\
\text { Öncesi }\end{array}$ & $\begin{array}{c}\text { TMS } \\
\text { Sonrası }\end{array}$ & $\begin{array}{l}\text { TMS } \\
\text { Öncesi }\end{array}$ & $\begin{array}{c}\text { TMS } \\
\text { Sonrası }\end{array}$ \\
\hline $\begin{array}{c}\text { Alınan } \\
\text { Primler/Top. } \\
\text { Özsermaye Oranı }\end{array}$ & 2.34 & 2.40 & 1.47 & 1.37 & 3.70 & 3.09 & 0.90 & 0.51 \\
\hline $\begin{array}{c}\text { Top. } \\
\text { Özsermaye/Varlık } \\
\text { Toplamı Oranı } \\
\end{array}$ & 0.42 & 0.31 & 0.29 & 0.23 & 0.55 & 0.47 & 0.10 & 0.07 \\
\hline $\begin{array}{c}\text { Top. } \\
\text { Özsermaye/Teknik } \\
\text { Karşılıklar (Net) } \\
\text { Oranı }\end{array}$ & 1.07 & 0.60 & 0.59 & 0.36 & 1.60 & 1.13 & 0.38 & 0.24 \\
\hline $\begin{array}{c}\text { Sermaye Yeterlilik } \\
\text { Oranı }\end{array}$ & 2.10 & 1.11 & 0.50 & 0.50 & 3.32 & 1.49 & 0.98 & 0.34 \\
\hline $\begin{array}{c}\text { Likit } \\
\text { Varlıklar/Varlık } \\
\text { Toplamı Oranı }\end{array}$ & 0.32 & 0.52 & 0.31 & 0.43 & 0.35 & 0.63 & 0.01 & 0.06 \\
\hline Cari Oran & 1.15 & 1.19 & 1.02 & 1.06 & 1.24 & 1.53 & 0.07 & 0.12 \\
\hline $\begin{array}{c}\text { Prim ve Reasürans } \\
\text { Alacakları/Varlık } \\
\text { Toplamı Oranı }\end{array}$ & 0.69 & 0.51 & 0.44 & 0.37 & 1.10 & 0.62 & 0.28 & 0.07 \\
\hline Likidite Oranı & 0.55 & 0.74 & 0.50 & 0.66 & 0.63 & 0.86 & 0.05 & 0.06 \\
\hline $\begin{array}{c}\text { Tazminat Tediye } \\
\text { Oranı }\end{array}$ & 0.65 & 0.75 & 0.62 & 0.69 & 0.69 & 0.82 & 0.02 & 0.05 \\
\hline $\begin{array}{c}\text { Konservasyon } \\
\text { Oranı }\end{array}$ & 0.63 & 0.79 & 0.57 & 0.75 & 0.68 & 0.83 & 0.04 & 0.02 \\
\hline $\begin{array}{c}\text { Teknik Karşılık } \\
\text { Oranı }\end{array}$ & 0.03 & 0.02 & 0.00 & -0.04 & 0.07 & 0.05 & 0.02 & 0.03 \\
\hline $\begin{array}{c}\text { Reasürans } \\
\text { Komisyon Oranı }\end{array}$ & 0.19 & 0.18 & 0.20 & 0.17 & 0.20 & 0.20 & 0.00 & 0.00 \\
\hline $\begin{array}{c}\text { Aracı Komisyon } \\
\text { Oranı }\end{array}$ & 0.14 & 0.15 & 0.14 & 0.14 & 0.15 & 0.17 & 0.00 & 0.00 \\
\hline Prim Artış Oranı & 0.26 & 0.17 & 0.16 & 0.04 & 0.36 & 0.32 & 0.07 & 0.09 \\
\hline Hasar Prim Oranı & 0.65 & 0.69 & 0.63 & 0.38 & 0.69 & 0.80 & 0.02 & 0.11 \\
\hline
\end{tabular}


Tablo 6: Tanımlayıcı İstatistik Sonuçları (Devam)

\begin{tabular}{|c|c|c|c|c|c|c|c|c|}
\hline Aktif Karlık Oranı & 0.05 & 0.01 & 0.02 & -0.03 & 0.07 & 0.06 & 0.01 & 0.03 \\
\hline $\begin{array}{c}\text { Özsermaye Karlık } \\
\text { Oranı }\end{array}$ & 0.14 & 0.06 & 0.05 & -0.10 & 0.27 & 0.21 & 0.08 & 0.10 \\
\hline $\begin{array}{c}\text { Teknik Karlıık } \\
\text { Oranı }\end{array}$ & 0.03 & 0.02 & 0.00 & -0.04 & 0.07 & 0.05 & 0.02 & 0.03 \\
\hline Masraf Oranı & 0.21 & 0.23 & 0.21 & 0.20 & 0.22 & 0.26 & 0.00 & 0.02 \\
\hline Bileşik Oran & 0.86 & 0.96 & 0.84 & 0.92 & 0.90 & 1.04 & 0.02 & 0.03 \\
\hline
\end{tabular}

3.6.2. Normallik Sinaması Testi

Sigorta sektöründe faaliyet gösteren şirketlerin finansal tablolarından elde edilen finansal oranlarda, TMS öncesi ve sonrası dönemler için istatistiksel açıdan farklılık veya anlamlı bir ilişkinin olup olmadığını test etmek için Wilcoxon İşaretli Sıralar Testi kullanılmıştır. Bu testin kullanılabilmesi için öncelikle analizde kullanılan finansal oranların veya değişkenlerin normal dağılıma uygun olup olmadığ 1 test edilmelidir. Daha sonra ise normallik sinaması testinin bulgularına göre Wilcoxon İşaretli Sıralar Testi analizi yapılmalıdır. Normallik sınaması testinde Kolmogorov-Smirnov ve Shapiro-Wilk testleri kullanılmıştır.

Tablo 7: Kolmogorov-Smirnov ve Shapiro-Wilk Testi Sonuçları

\begin{tabular}{|c|c|c|c|c|c|c|c|c|c|c|c|}
\hline \multirow{2}{*}{\multicolumn{2}{|c|}{ Finansal Oranlar }} & \multicolumn{4}{|c|}{ Kolmogorov- Smirl Shapiro-Wilk } & \multirow{2}{*}{\multicolumn{2}{|c|}{ Finansal Oranlar }} & \multicolumn{4}{|c|}{ Kolmogorov-Smil Shapiro-Wilk } \\
\hline & & \multirow{2}{*}{\begin{tabular}{|c|} 
Statistic \\
0,307
\end{tabular}} & \multirow{2}{*}{$\begin{array}{l}\text { Sig. } \\
0,008\end{array}$} & \multirow{2}{*}{$\begin{array}{c}\text { Statistic } \\
0,814\end{array}$} & \multirow{2}{*}{$\begin{array}{l}\text { Sig. } \\
0,022\end{array}$} & & & \multirow{2}{*}{\begin{tabular}{|c} 
Statis tic \\
0,233
\end{tabular}} & \multirow{2}{*}{$\begin{array}{l}\text { Sig. } \\
0,001\end{array}$} & \multirow{2}{*}{$\frac{\text { Statistic }}{0,884}$} & \multirow{2}{*}{$\frac{\text { Sig. }}{0}$} \\
\hline APÖ & TMS Öncesi & & & & & IKKO & TMS Öncesi & & & & \\
\hline & TMS Sonrası & 0,147 & 0 & 0,949 & 0,001 & 1ков & TMS Sonrası & 0,246 & 0,009 & 0,897 & 0,001 \\
\hline \multirow{2}{*}{ ÖVT } & TMS Öncesi & 0,285 & 0,021 & 0,848 & 0 & \multirow{2}{*}{ RKO } & TMS Öncesi & 0,294 & 0,015 & 0,777 & 0,008 \\
\hline & TMS Sonrası & 0,181 & 0 & 0,916 & 0 & & TMS Sonrası & 0,136 & 0 & 0,971 & 0 \\
\hline \multirow{2}{*}{ ӧтк } & TMS Öncesi & 0,234 & 0 & 0,877 & 0 & \multirow{2}{*}{ AKO } & TMS Öncesi & 0,259 & 0,015 & 0,856 & 0,002 \\
\hline & TMS Sonrası & 0,220 & 0 & 0,857 & 0 & & TMS Sonrası & 0,144 & 0 & 0,980 & 0 \\
\hline \multirow{2}{*}{ SYO } & TMS Öncesi & 0,245 & 0,012 & 0,881 & 0 & \multirow{2}{*}{ ARO } & TMS Öncesi & 0,198 & 0 & 0,900 & 0 \\
\hline & \begin{tabular}{|l|} 
TMS Sonrasi \\
\end{tabular} & 0,234 & 0,027 & 0,844 & 0 & & \begin{tabular}{|l|} 
TMS Sonrası \\
\end{tabular} & 0,161 & 0 & 0,945 & 0 \\
\hline \multirow{2}{*}{ LVO } & TMS Öncesi & 0,172 & 0 & 0,908 & 0 & \multirow{2}{*}{ HPO } & TMS Öncesi & 0,255 & 0 & 0,887 & 0 \\
\hline & TMS Sonrası & 0,162 & 0 & 0,969 & 0 & & TMS Sonrası & 0,36 & 0,001 & 0,670 & 0 \\
\hline \multirow{2}{*}{ CO } & TMS Öncesi & 0,235 & 0,001 & 0,86 & 0,001 & \multirow{2}{*}{ AO } & TMS Öncesi & 0,221 & 0,008 & 0,878 & 0 \\
\hline & TMS Sonrası & 0,347 & 0,001 & 0,721 & 0,002 & & TMS Sonrası & 0,19 & 0 & 0,952 & 0,003 \\
\hline \multirow{2}{*}{ PRA } & TMS Öncesi & 0,313 & 0,004 & 0,791 & 0,011 & \multirow{2}{*}{ ӧко } & TMS Öncesi & 0,283 & 0,023 & 0,858 & 0,002 \\
\hline & \begin{tabular}{|l|} 
TMS Sonrası \\
\end{tabular} & 0,154 & 0 & 0,973 & 0,007 & & \begin{tabular}{|l|} 
TMS Sonrası \\
\end{tabular} & 0,185 & 0 & 0,940 & 0 \\
\hline \multirow{2}{*}{ LO } & TMS Öncesi & 0,272 & 0,034 & 0,84 & 0 & \multirow{2}{*}{ TKO } & TMS Öncesi & 0,233 & 0,001 & 0,884 & 0 \\
\hline & TMS Sonrası & 0,124 & 0 & 0,966 & 0 & & TMS Sonrası & 0,246 & 0 & 0,897 & 0 \\
\hline \multirow{2}{*}{ TDO } & TMS Öncesi & 0,180 & 0 & 0,900 & 0 & \multirow{2}{*}{ MO } & TMS Öncesi & 0,141 & 0 & 0,925 & 0,001 \\
\hline & \begin{tabular}{|l|} 
TMS Sonrası \\
\end{tabular} & 0,212 & 0 & 0,898 & 0 & & \begin{tabular}{|l|} 
TMS Sonrası \\
\end{tabular} & 0,152 & 0 & 0,938 & 0,002 \\
\hline \multirow{2}{*}{ KO } & TMS Öncesi & 0,233 & 0,031 & 0,861 & 0 & \multirow{2}{*}{ BO } & TMS Öncesi & 0,144 & 0 & 0,920 & 0 \\
\hline & TMS Sonrası & 0,328 & 0,003 & 0,857 & 0 & & TMS Sonrası & 0,154 & 0 & 0,950 & 0 \\
\hline
\end{tabular}


Analiz kapsamında incelenen sigorta şirketlerinin TMS öncesi ve sonrası dönemlerindeki verileri kullanılarak elde edilen finansal oranlarının normallik sinaması testi Tablo 7'de sunulmuştur. Buna göre, finansal oranların hepsinin anlamlılık düzeylerinin $\% 5$ 'in altında $(\mathrm{p}<0,05)$ olması ve dolayısıyla da normal dağılıma uygunluk göstermemesi sebebiyle parametrik olmayan testlerden Wilcoxon İşaretli Sıralar Testi uygulanmasına karar verilmiştir.

\subsubsection{Wilcoxon İşaretli Sıralar Testi Bulguları}

Wilcoxon İşaretli Sıralar Testi sonuçları Tablo 8'de sunulmuştur. Wilcoxon Testi, eşli örneklem t-testinin parametrik olmayan karşılığıdır. Bu testte iki değişkenin aralıklı/oranlı olmadığı ve verilerin normal dağılmadığı varsayılır.

Tablo 8: Wilcoxon İşaretli Sıralar Testi Sonuçları

\begin{tabular}{|c|c|c|c|c|c|c|}
\hline Finansal Oranlar & $\begin{array}{c}\text { Son Test - Ön } \\
\text { Test }\end{array}$ & $\mathbf{N}$ & $\begin{array}{c}\text { Sira } \\
\text { Ortalaması }\end{array}$ & $\begin{array}{c}\text { Sira } \\
\text { Toplamı }\end{array}$ & $\begin{array}{c}\mathrm{Z} \\
\text { İstatistiği }\end{array}$ & $\begin{array}{c}\text { Anlamlılık } \\
\text { (p değeri) }\end{array}$ \\
\hline \multirow{4}{*}{ 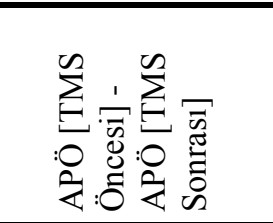 } & Negatif Sira & $6^{\mathrm{a}}$ & 5,00 & 30,00 & $-0,255^{*}$ & 0,799 \\
\hline & Pozitif Sira & $4^{b}$ & 6,25 & 25,00 & & \\
\hline & Eşit & $0^{\mathrm{c}}$ & & & & \\
\hline & Toplam & 10 & & & & \\
\hline \multirow{4}{*}{ 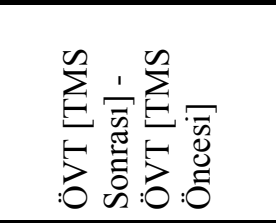 } & Negatif Sira & $7^{d}$ & 6,57 & 46,00 & $-1,886^{*}$ & $0,059^{*: \cdots *: *}$ \\
\hline & Pozitif Sira & $3^{\mathrm{e}}$ & 3,00 & 9,00 & & \\
\hline & Eşit & $\overline{0^{f}}$ & & & & \\
\hline & Toplam & 10 & & & & \\
\hline \multirow{4}{*}{ 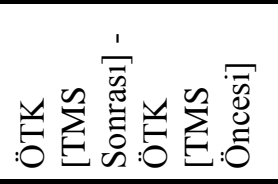 } & Negatif Sira & $8^{g}$ & 6,13 & 49,00 & $-2,191^{*}$ & $0,028^{* * * *}$ \\
\hline & Pozitif Sıra & $2^{h}$ & 3,00 & 6,00 & & \\
\hline & Eşit & $0^{i}$ & & & & \\
\hline & Toplam & 10 & & & & \\
\hline \multirow{4}{*}{ 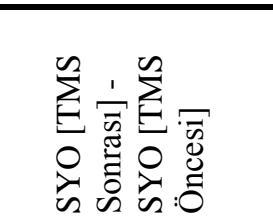 } & Negatif Sira & $8^{j}$ & 5,13 & 45,00 & $-2,100^{*}$ & $0,027^{* \pi}$ \\
\hline & Pozitif Sira & $2^{k}$ & 3,00 & 6,00 & & \\
\hline & Eşit & $0^{1}$ & & & & \\
\hline & Toplam & 10 & & & & \\
\hline \multirow{4}{*}{ 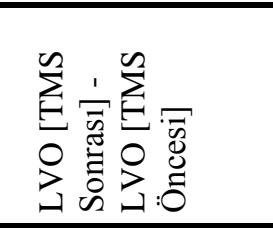 } & Negatif Sira & $0^{\mathrm{m}}$ & 00 &, 00 & $-2,803^{*}$ & $0,005^{* * *}$ \\
\hline & Pozitif Sıra & $10^{\mathrm{n}}$ & 5,50 & 55,00 & & \\
\hline & Eşit & $0^{\circ}$ & & & & \\
\hline & Toplam & 10 & & & & \\
\hline \multirow{4}{*}{ 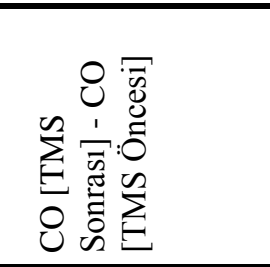 } & Negatif Sira & $4^{p}$ & 5,25 & 21,00 & $-0,663^{*}$ & 0,508 \\
\hline & Pozitif Sira & $6^{q}$ & 5,67 & 34,00 & & \\
\hline & Eşit & $0^{\mathrm{r}}$ & & & & \\
\hline & Toplam & 10 & & & & \\
\hline
\end{tabular}


Tablo 8: Wilcoxon İşaretli Sıralar Testi Sonuçları (Devam)

\begin{tabular}{|c|c|c|c|c|c|c|}
\hline \multirow{4}{*}{ 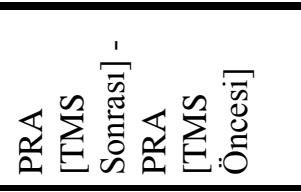 } & Negatif Sira & $6^{s}$ & 6,17 & 37,00 & $-0,968^{*}$ & 0,333 \\
\hline & Pozitif Sıra & $4^{t}$ & 4,50 & 18,00 & & \\
\hline & Eşit & $0^{\mathrm{u}}$ & & & & \\
\hline & Toplam & 10 & & & & \\
\hline \multirow{4}{*}{ 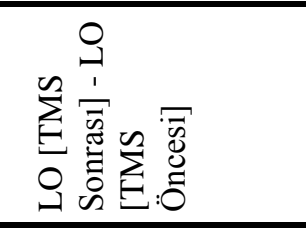 } & Negatif Sira & $0^{\mathrm{v}}$ & ,00 & , 00 & $-2,709^{*}$ & $0,005^{* * *}$ \\
\hline & Pozitif Sira & $10^{\mathrm{w}}$ & 4,50 & 52,00 & & \\
\hline & Eşit & $0^{x}$ & & & & \\
\hline & Toplam & 10 & & & & \\
\hline \multirow{4}{*}{ 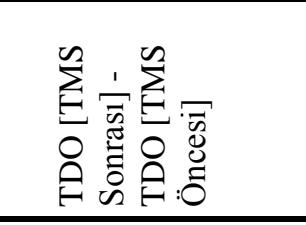 } & Negatif Sira & $0^{\mathrm{y}}$ &, 00 &, 00 & $-2,121^{*}$ & $0,004^{* * *}$ \\
\hline & Pozitif Sura & $10^{z}$ & 5,50 & 55,00 & & \\
\hline & Eşit & $0^{\mathrm{aa}}$ & & & & \\
\hline & Toplam & 10 & & & & \\
\hline \multirow{4}{*}{ 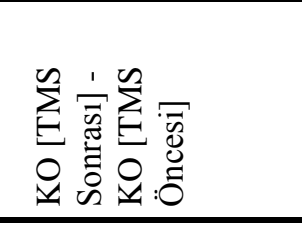 } & Negatif Sira & $0^{\mathrm{ab}}$ &, 00 &, 00 & $-2,803^{*}$ & $0,005^{* * \pi}$ \\
\hline & Pozitif Sira & $10^{\mathrm{ac}}$ & 5,50 & 55,00 & & \\
\hline & Eşit & $0^{\mathrm{ad}}$ & & & & \\
\hline & Toplam & 10 & & & & \\
\hline \multirow{4}{*}{ 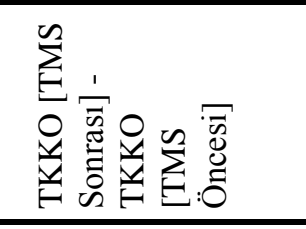 } & Negatif Sira & $7^{\text {ae }}$ & 5,64 & 39,50 & $-1,224^{*}$ & 0,221 \\
\hline & Pozitif Sıra & $3^{\text {af }}$ & 5,17 & 15,50 & & \\
\hline & Eşit & $0^{\mathrm{ag}}$ & & & & \\
\hline & Toplam & 10 & & & & \\
\hline \multirow{4}{*}{ 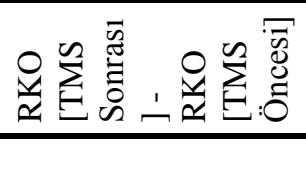 } & Negatif Sira & $10^{\text {ah }}$ & $\overline{5,50}$ & 55,00 & $-1,921^{*}$ & $0,005^{* * *}$ \\
\hline & Pozitif Sıra & $0^{\mathrm{ai}}$ &, 00 &, 00 & & \\
\hline & Eşit & $0^{\mathrm{aj}}$ & & & & \\
\hline & Toplam & 10 & & & & \\
\hline \multirow{4}{*}{ 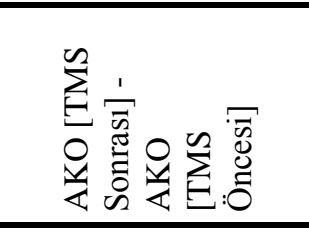 } & Negatif Sira & $2^{\mathrm{ak}}$ & 4,50 & 9,00 & $-1,886^{*}$ & $0,059^{* *+1}$ \\
\hline & Pozitif Sıra & $8^{\text {al }}$ & 5,75 & 46,00 & & \\
\hline & Eşit & $0^{\mathrm{am}}$ & & & & \\
\hline & Toplam & 10 & & & & \\
\hline \multirow{4}{*}{ 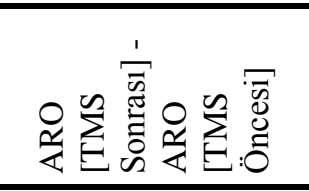 } & Negatif Sira & $7^{\text {an }}$ & 6,14 & 43,00 & $-1,580^{*}$ & 0,114 \\
\hline & Pozitif Sura & $3^{a 0}$ & 4,00 & 12,00 & & \\
\hline & Eşit & $0^{\mathrm{ap}}$ & & & & \\
\hline & Toplam & 10 & & & & \\
\hline \multirow{4}{*}{ 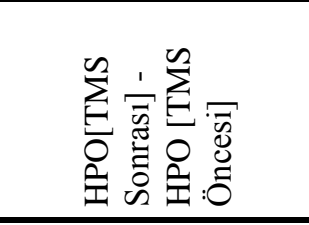 } & Negatif Sira & $1^{a q}$ & 10,00 & 10,00 & $-1,784^{*}$ & $0,074^{*}$ \\
\hline & Pozitif Sura & $9^{\mathrm{ar}}$ & 15,00 & 45,00 & & \\
\hline & Eşit & $0^{\text {as }}$ & & & & \\
\hline & Toplam & 10 & & & & \\
\hline \multirow{2}{*}{ n } & Negatif Sira & $9^{\text {at }}$ & 5,78 & 52,00 & $-2,497^{*}$ & $0,013^{* * * *}$ \\
\hline & Pozitif Sira & $1^{\text {au }}$ & 3,00 & 3,00 & & \\
\hline
\end{tabular}


Tablo 8: Wilcoxon İşaretli Sıralar Testi Sonuçları (Devam)

\begin{tabular}{|c|c|c|c|c|c|c|}
\hline & Eşit & $0^{\text {av }}$ & & & & \\
\hline & Toplam & 10 & & & & \\
\hline \multirow{4}{*}{ 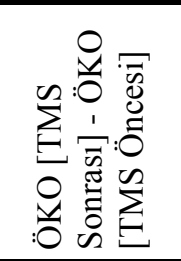 } & Negatif Sira & $8^{\mathrm{aw}}$ & 5,50 & 44,00 & $-1,682^{*}$ & 0,093 \\
\hline & Pozitif Sıra & $2^{\mathrm{ax}}$ & 5,50 & 11,00 & & \\
\hline & Eşit & $0^{\mathrm{ay}}$ & & & & \\
\hline & Toplam & 10 & & & & \\
\hline \multirow{4}{*}{ 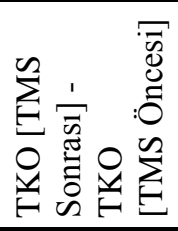 } & Negatif Sira & $7^{\mathrm{az}}$ & 5,64 & 39,50 & $-1,224^{*}$ & 0,221 \\
\hline & Pozitif Sira & $3^{\mathrm{ba}}$ & 5,17 & 15,50 & & \\
\hline & Eşit & $0^{\mathrm{bb}}$ & & & & \\
\hline & Toplam & 10 & & & & \\
\hline \multirow{4}{*}{ 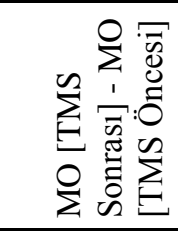 } & Negatif Sira & $2^{\mathrm{bc}}$ & 3,50 & 7,00 & $-2,090^{*}$ & $0,037^{\text {***;* }}$ \\
\hline & Pozitif Sira & $8^{\text {bd }}$ & 6,00 & 48,00 & & \\
\hline & Eşit & $0^{\mathrm{be}}$ & & & & \\
\hline & Toplam & 10 & & & & \\
\hline \multirow{4}{*}{ 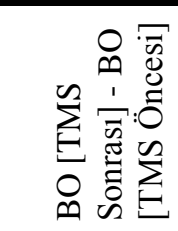 } & Negatif Sira & $0^{\mathrm{bf}}$ &, 00 & ,00 & $-2,803^{*}$ & $0,005^{* \%}$ \\
\hline & Pozitif Sura & $10^{\mathrm{bg}}$ & 5,50 & 55,00 & & \\
\hline & Eşit & $0^{\text {bh }}$ & & & & \\
\hline & Toplam & 10 & & & & \\
\hline
\end{tabular}

(") Negatif sıralar temeline dayalı, $\left(^{* *}\right) \% 1$ düzeyinde anlamlı, $\left({ }^{* * *}\right) \% 5$ düzeyinde anlamlı, $\left({ }^{* * * * *}\right)$ $\% 10$ düzeyinde anlamlı $\left(^{* *} \mathrm{p}<, 01,{ }^{* * *} \mathrm{p}<, 05,{ }^{* * * *} \mathrm{p}<, 10\right)$.
a. son test $<$ ön test
b. son test $>$ ön test
c. son test $=$ ön test

Tablo 8'de sunulan sonuçlara göre, sigorta sektöründe faaliyet gösteren şirketlerin TMS öncesi ve sonrası dönemlerdeki finansal oranlardan; APÖ, CO, PRA, TKKO, ARO, ÖKO ve TKO'da istatistiksel açıdan anlamlı bir farklılı̆̆ın olmadı̆̆ı, diğer 13 finansal oranda ise istatistiksel açıdan (\%1, \%5 ve \%10 düzeyinde) anlamlı bir farklılığın olduğu tespit edilmiştir. Elde edilen bulgular aşağıda açıklanmıştır;

Wilcoxon işaretli sıralar testi sonuçlarına göre, Top.Özsermaye/Varlık Toplamı Oranının [ÖVT], TMS öncesi ve sonrası dönemleri karşılaştırıldığında istatistiksel açıdan güçlü olmasa da anlamlı bir fark olduğu tespit edilmiştir $(\mathrm{z}=1,886$, $\mathrm{p}<, 10)$. Fark puanlarının sıra ortalaması ve toplamları dikkate alındığında, gözlenen bu farkın negatif sıralar yani ön-test puanı lehine olduğu görülmektedir. Diğer bir ifadeyle, TMS uygulamalarının ÖVT üzerinde önemli bir etkiye sahip olmadığı söylenebilir. 
Daha önce de ifade edildiği üzere, ÖVT'nin yüksek olması sigorta şirketinin sermaye yapısının güçlü olduğunu ve uzun vadede borçlarını ödeme gücünün bulunduğunu gösterir. $\mathrm{Bu}$ durumda sigorta şirketlerinin TMS uygulamaları öncesinde sermaye yapısının veya gücünün daha etkin olduğu söylenebilir.

Toplam Özsermaye/Teknik Karşılıklar oranı [ÖTK] ve Sermaye Yeterlilik oranında [SYO], TMS öncesi ve sonrası dönemlerde istatistiksel açıdan anlamlı bir fark olduğu tespit edilmiştir $(\mathrm{z}=2,191, \mathrm{p}<, 05 ; \mathrm{z}=2,100, \mathrm{p}<, 05)$. Fark puanlarının sıra ortalaması ve toplamları dikkate alındığında, gözlenen bu farkın negatif sıralar yani ön-test puanı lehine olduğu görülmektedir. Diğer bir ifadeyle TMS uygulamalarının ÖTK ve SYO üzerinde olumsuz bir etkiye sahip olduğu söylenebilir. Daha önce de ifade edildiği üzere, ÖTK'nin yüksek olması sigorta şirketinin sermaye yapısının güçlü olduğunu ve uzun vadede borçlarını ödeme gücünün bulunduğunu gösterir. $\mathrm{Bu}$ kapsamda TMS uygulamalarının sigorta şirketlerinin sermaye yapısı üzerinde olumlu bir etkiye sahip olmadığı; diğer bir ifadeyle ÖTK ve SYO kapsamında, sigorta şirketlerinin TMS uygulamaları öncesinde sermaye yapısının veya gücünün daha etkin olduğunu ifade etmek mümkündür. Elde edilen bu bulgular, ÖVT için bulunan sonucu desteklemektedir.

Likidite ve aktif kalitesine ilişkin finansal oranlardan, Likit Varlıklar/Varlık Toplamı [LVO] ve Likidite Oranının[LO], TMS öncesi ve sonrası dönemleri karşılaştırıldığında istatistiksel açıdan güçlü ve anlamlı bir fark olduğu tespit edilmiştir $(\mathrm{z}=2,803, \mathrm{p}<, 01 ; \mathrm{z}=2,709, \mathrm{p}<, 01)$. Fark puanlarının sıra ortalaması ve toplamları dikkate alındığında, gözlenen bu farkın pozitif sıralar, yani son-test puanı lehine olduğu görülmektedir. Yani TMS uygulamalarının LVO ve LO üzerinde olumlu bir etkiye sahip olduğu söylenebilir. Daha önce de ifade edildiği üzere, LVO ve LO, sigorta şirketlerinin toplam varlıkları içerisindeki likit varlıklarının seviyesini gösterir. Bu oranın yüksek olması, sigorta şirketlilerinin yükümlülüklerini yerine getirebilme veya borçlarını ödeyebilme gücünün ve likidite durumunun güçlü olduğunu göstergesidir. Buna göre TMS uygulamalarından sonra sigorta şirketlerinin likidite durumunun güçlendiği; diğer bir ifadeyle, sigorta şirketlerinin TMS uygulamaları sonrasında nakit gücünün daha etkin olduğu söylenebilir.

Sigorta şirketlerinin faaliyet etkinliği ile ilgili oranlardan Tazminat Tediye Oranı [TDO], Konservasyon Oranı [KO], Reasürans Komisyon Oranı [RKO] ve Aracı Komisyon Oranında [AKO] istatistiksel açıdan anlamlı bir fark olduğu tespit edilmiştir ( $\mathrm{z}=2,121, \mathrm{p}<, 01 ; \mathrm{z}=2,803, \mathrm{p}<, 01 ; \mathrm{z}=1,921, \mathrm{p}<, 01 ; \mathrm{z}=1,886, \mathrm{p}<, 10)$. Fark puanlarının sıra ortalaması ve toplamları dikkate alındığında, gözlenen bu farkın TDO, KO ve AKO için pozitif sıralar, yani son-test puanı lehine; buna karşılık RKO için ise fark puanlarının sıra ortalaması ve toplamları negatif sıralar, yani ön-test puanı lehine olduğu görülmektedir. Daha önce de ifade edildiği üzere TDO, sigorta faaliyetleri kapsamında muhtemel hasarların ne kadarlık kısmının sigorta şirketleri tarafından sigortalılara tazminat olarak ödendiğini gösterir. 
Oranın yüksek olması gerekmektedir. KO’nun, yüksek olması sigorta şirketinin muhtemel risklerden yüksek pay aldığını gösterirken, düşük olması şirketin riskten kaçındığının göstergesidir. $\mathrm{Bu}$ sonuç TDO ve KO oranları kapsamında sigorta şirketlerinin faaliyet etkinliklerinin TMS uygulamalarına geçilmesiyle birlikte arttığı veya bu durumun sigorta şirketlerinin faaliyet etkinliği lehine sonuçlandığı şeklinde yorumlanabilir.

TMS öncesi ve sonrası dönemler bakımından şirketlerin karlılığında genellikle istatistiksel açıdan anlamlı bir fark olduğu tespit edilmiştir. Bu oranlar; Hasar Prim Oranı[HPO] $(\mathrm{z}=1,784, \mathrm{p}<, 10)$, Aktif Karlılık Oranı [AO] $(\mathrm{z}=2,497, \mathrm{p}<, 05)$, Masraf Oranı [MO] $(\mathrm{z}=2,090, \mathrm{p}<, 05)$ ve Bileşik Orandır [BO] $(\mathrm{z}=2,803, \mathrm{p}<, 01)$. Fark puanlarının sıra ortalaması ve toplamları dikkate alındığında, gözlenen bu farkın HPO, MO ve BO için pozitif sıralar yani son-test puanı lehine olduğu görülmektedir. RKO için ise, fark puanlarının sıra ortalaması ve toplamları negatif sıralar yani ön-test puanı lehinedir. Buna göre TMS uygulamalarından sonra sigorta şirketlerinin karlılık durumunun güçlendiği söylenebilir. Diğer bir ifadeyle, sigorta şirketlerinin TMS'yi uygulamaları sonrasında karlılık oranlarında bir artış olduğunu ifade etmek mümkündür.

\section{Sonuç}

Sigorta şirketlerinin muhasebe uygulamalarındaki farklı özellikler finansal tablolarında, finansal oranların hesaplanmasinda ve yorumlanmasinda da görülmektedir. Sigorta şirketlerinin faaliyetleri sonucunda oluşan finansal tablolarının istenilen düzeyde yararlı olabilmesi ve mevcut farklılıkların ortadan kaldırılması için uluslararası düzenlemeler kapsamında bazı çalışmaların yapılması gerekmiştir. Bu kapsamda ülkemiz sigorta sektöründe, 01.01.2008 tarihinde UFRS'yle uyumlu muhasebe standartları seti olan ve TMSK tarafindan yayımlanan Türkiye Muhasebe Standartları (TMS) uygulanmaya başlanmıştır.

$\mathrm{Bu}$ çalışmanın amacı, Türkiye Muhasebe Standartlarının (TMS) sigorta sektörü üzerindeki etkilerini belirlemektir. Çalışmanın amacı doğrultusunda, 2003-2017 yı1ları arasında hayat dışı branşlarda faaliyet gösteren sigorta şirketlerinin sektöre özgü 20 adet temel finansal oranı yıllar itibariyle karşılaştırılmalı olarak hesaplanmış ve değerlendirilmiştir. Daha sonra bu oranlarda, TMS öncesi (20032007) ve sonrası (2007-2017) dönemlerde istatistiksel açıdan anlamlı bir fark olup olmadığ1 incelenmiş ve anlamlılık düzeyleri test edilmiştir. Bu kapsamda çalışmada veri analizi iki aşamalı olarak gerçekleşmiştir. Birinci aşamada sigorta sektöründe faaliyet gösteren şirketlerin verileri kullanılarak ve finansal oran analizi yöntemi uygulanarak, TMS öncesi ve sonrası dönemlerde finansal oranlar açısından yıllar itibariyle farklılık olup olmadığı hesaplanmış ve değerlendirilmiştir. İkinci aşamada ise bu oranlarda, TMS öncesi ve sonrası dönemlerde istatistiksel açıdan anlamlı bir fark olup olmadığı Wilcoxon İşaretli Sıralar Testi ile analiz edilmiştir. 
Çalışmanın finansal oran analizi sonucunda elde edilen bulgulara göre, TMS'nin hayata geçirilmesi neticesinde hayat dişı sigortacılık sektöründe; Alınan Primler/Top. Özsermaye Oranı, Likit Varlıklar/Varlık Toplamı Oranı, Cari Oran, Likidite Oran1, Konservasyon Oran1, Arac1 Komisyon Oran1, Tazminat Tediye Oranı, Masraf Oranı ve Birleşik Oranda artış meydana gelmiştir.

Buna karşı1ık; Özsermaye/Varlık Toplamı Oranı, Özsermaye/ Teknik Karşılıklar Oran1, Sermaye Yeterlilik Oranı, Prim ve Reasürans Alacakları/ Varlık Toplamı Oranı, Teknik Karşılık Oranı, Reasürans Komisyon Oranı, Prim Artış Oranı, Teknik Karlılık Oranı ve Özsermaye Karlılık Oranı azalmıştır.

Hasar Prim Oranında ise herhangi bir değişim olmamıştır.

Çalışmanın Wilcoxon İşaretli Sıralar Testi analizi sonucunda elde edilen bulgular ise aşağıda değerlendirilmiştir.

- Sermaye yeterliliğine ilişkin finansal oranlardan Alınan Primler/Toplam Özsermaye Oranı'nda [APÖ] TMS öncesi ve sonrası dönemler kıyaslandığında istatistiksel açıdan anlamlı bir farklılığın olmadığı tespit edilmiştir.

- Toplam Özsermaye/Varlık Toplamı Oranı’nda [ÖVT], TMS öncesi ve sonrası dönemler karşılaştırıldığında istatistiksel açıdan güçlü olmasa da anlamlı bir fark olduğu tespit edilmiştir. Analiz sonucuna göre TMS uygulamalarının sigorta şirketlerinin sermaye yapısı üzerinde olumlu bir etkiye sahip olmadığı; başka bir ifade ile TMS uygulamaları öncesinde sigorta şirketlerinin sermaye yapısının veya gücünün daha etkin olduğu söylenebilir.

- Toplam Özsermaye/Teknik Karş1lıklar [ÖTK] ve Sermaye Yeterlilik oranlarında [SYO], TMS öncesi ve sonrası dönemler karşılaştırıldığında istatistiksel açıdan anlamlı bir fark olduğu tespit edilmiştir. Fark puanlarının sira ortalaması ve toplamları dikkate alındığında, gözlenen bu farkın negatif sıralar yani ön-test puanı lehine olduğu tespit edilmiştir. Bu sonuç, TMS uygulamalarının ÖTK ve SYO üzerinde olumsuz bir etkiye sahip olduğunu gösterir.

- Likidite ve Aktif Kalitesine ilişkin finansal oranlardan, Cari Oran'ın [CO] TMS öncesi ve sonrası dönemler itibariyle kıyaslanması neticesinde istatistiksel açıdan anlamlı bir farklılığın olmadığı tespit edilmiştir.

- Likit Varlıklar/Varlık Toplamı [LVO] ve Likidite Oranı'nda [LO], TMS öncesi ve sonrası dönemler karşılaştırıldığında istatistiksel açıdan güçlü ve anlamlı bir fark olduğu tespit edilmiştir. Fark puanlarının sıra ortalaması ve toplamları dikkate alındığında, gözlenen bu farkın pozitif sıralar yani son-test puanı lehine olduğu görülmektedir. Yani TMS uygulamalarının LVO ve LO üzerinde olumlu bir etkiye sahip olduğu söylenebilir. 
- Teknik Karşı1lık Oranı[TKKO] ve Prim Artış Oranı'nda [ARO] TMS öncesi ve sonrası dönemler kıyaslandığında istatistiksel açıdan anlamlı bir farklılığın olmadığ 1 tespit edilmiştir.

- Tazminat Tediye Oranı [TDO], Konservasyon Oranı [KO], Reasürans Komisyon Oranı [RKO] ve Aracı Komisyon Oranı ile [AKO] ilgili bulunan değerlerde TMS öncesi ve sonrası dönemlerde istatistiksel açıdan anlamlı bir farkın olduğu tespit edilmiştir. Fark puanlarının sıra ortalaması ve toplamları dikkate alındığında, gözlenen bu farkın TDO, KO ve AKO için pozitif sıralar yani son-test puanı lehine olduğu tespit edilmiştir. RKO için ise, fark puanlarının sıra ortalaması ve toplamları negatif sıralar yani ön-test puanı lehinedir. $\mathrm{Bu}$ sonuç TDO ve KO oranları kapsamında sigorta şirketlerinin faaliyet etkinliklerinin TMS uygulamalarına geçilmesiyle birlikte arttığı veya bu durumun sigorta şirketlerinin faaliyet etkinliği lehine sonuçlandığı şeklinde yorumlanabilir.

- TMS öncesi ve sonrası dönemler bakımından şirketlerin karlığında genellikle istatistiksel açıdan anlamlı bir fark olduğu tespit edilmiştir. Bu oranlar; Hasar Prim Oranı [HPO], Aktif Karlılık Oranı [AO], Masraf Oranı [MO] ve Bileşik Oran'dır [BO]. Fark puanlarının sıra ortalaması ve toplamları dikkate alındığında, gözlenen bu farkın HPO, MO ve BO için pozitif sıralar yani sontest puanı lehine olduğu tespit edilmiştir. RKO için ise, fark puanlarının sıra ortalaması ve toplamları negatif sıralar yani ön-test puanı lehine olduğu belirlenmiştir. Buna göre TMS uygulamalarından sonra sigorta şirketlerinin karlılık durumunun güçlendiği ve sigorta şirketlerinin TMS uygulamaları sonrasında karlılık artışı olduğu söylenebilir.

Elde edilen sonuçlar literatürle kıyaslandığında; sigorta şirketlerinin finansal yapısını ele alan bazı çalışmalar bulunmakla birlikte, TMS'nin sigorta sektörü üzerindeki etkisini inceleyen çalışmanın olmadığı tespit edilmiştir. Ayrıca bu çalışmalarda genellikle sigorta şirketlerinin verileri kullanılarak, finansal oran analizi yöntemiyle, yıllar itibariyle karşılaştırmalı finansal ve içerik analizlerinin yapıldığı belirlenmiştir. Kısacası ülkemizde TMS'nin sigorta sektörü üzerindeki etkilerini inceleyen herhangi bir ampirik çalışmanın olmadığı sonucuna ulaşılmıştır. Bu kapsamda çalışma, Türkiye örnekleminde ilk defa yapılması açısından önemlidir.

Yukarıda açıklanan analiz sonuçlarının şu kısıtlar kapsamında değerlendirilmesi daha doğru olacaktır. Bu çalışma, Türk sigorta sektöründe 2003-2017 yılları arasında hayat dışı branşlarda faaliyet gösteren sigorta şirketlerinin tamamını kapsamakta olup; hayat ve bireysel emeklilik branşlarında faaliyet gösteren şirketleri kapsamamaktadır. Bu açıdan, araştırmada bulunan genel sonuçlar, hayat ve bireysel emeklilik branşlarında faaliyet gösteren şirketler için farklı sonuçlar gösterebilir. Çalışmada, TMS öncesi dönemler 2003-2007 yıllarını kapsamaktadır. Bunun nedeni, sigorta sektöründe TMS'nin 2008 y1lında uygulanmaya başlamasıdır. Ayrıca 2003 yılından önce sigorta sektörüne ilişkin sağlıklı verilere 
ulaşmak mümkün olmadığından, 2003 yılı öncesi veriler kullanılmamıştır. 20082017 yıllarını kapsayan TMS sonrası dönemin uzun tutulmasının nedeni ise, 2008 finansal krizinin yapılan analizleri olumsuz yönde etkilemesini engellemektir. Her ne kadar analizlerde kullanılan veriler yıllık ve ortalama olarak alındığından yapılan analizleri olumsuz yönde etkilememiş olsa da, yıl bazlı etkiler açısından ele alındığında, uzun vadeli verilerle çalışmanın daha anlamlı olacağı değerlendirilmiştir. Varlık yapıları sigorta şirketlerine göre çok farklı olan banka ve özel finans kurumları, finansal kiralama ve faktöring şirketleri, girişim sermayesi, yatırım şirketleri, menkul ve gayrimenkul yatırım ortaklıkları gibi diğer mali kuruluşlar araştırma kapsamı dışında tutulmuştur. BİST'de işlem gören sigorta şirketlerinin, sektörü temsil edemeyecek derecede az sayıda olması ve BİST dışındaki sigorta şirketlerinin ayrı ayrı şirket verilerine ulaşılmasının mümkün olmaması nedeniyle çalışmada sektörel analiz yapılmıştır. Analize dâhil edilen şirketlerin sektörel verilerine sadece dönem sonu finansal tablolarından ulaşılabildiği için, ara dönem finansal tablolara ait veriler analize dâhil edilmemiştir.

Çalışmanın kısıtları kapsamında gelecekte konuyla ilgili yapılacak çalışmalarda şu öneriler dikkate alınabilir. Bu çalışmada analiz kapsamına alınmayan ve verileri kullanılmayan, hayat branşlarında ve bireysel emeklilik sisteminde faaliyet gösteren sigorta şirketlerinin sektörel verileri kullanılarak analizler yapılabilir. Farklı sektörlerdeki sigorta şirketlerinin finansal yapıları ve oranları ile bunların yorumlanması çok farklıdır. Yapılacak çalışmalarda sektörlerin ayrı ayrı araştırılması literatüre önemli katkılar sağlayacaktır. Çalışmada kullanılan finansal oran analizi ve Wilcoxon İşaretli Sıralar Testi gibi yöntemlerin dışında anket gibi farklı istatistiksel yöntemlerin kullanılmasında fayda vardır. Bu kapsamda BİST'te işlem gören ve görmeyen şirketlerin TMS'ye yönelik yaklaşımlarının veya tutumlarının anket uygulanarak araştırılması, sektörde uygulanan TMS'nin durum tespiti için önemli olacaktır. Sigorta sektörünün, TMS öncesi ve sonras1 dönemlerdeki verilerinden yararlanarak, karlılık ve sermaye yapısı üzerinde etkili olabilecek finansal oranların araştırılması ayrı bir çalışma konusu olabilir. $\mathrm{Bu}$ sayede TMS'nin karlılık üzerindeki etkisinin tespiti literatüre önemli katkılar sağlayacaktır. BİST'te faaliyet gösteren ancak sayı olarak sigorta sektörünü temsil etmeyen sigorta şirketleri de ayrı bir çalışma konusu olabilir. Bu sayede BISTT'te işlem gören şirketlerin TMS'yi uygulama düzeylerinin belirlenmesi, karar alıcılar ve uygulayıcılar için önemli sonuçlar sağlayacaktır. Sigorta sektöründe, TMS öncesi ve sonrası dönemlerdeki farklı uygulamaların finansal tablolara ve raporlamaya etkileri muhasebe kayıtlarıyla incelenebilir. Böylelikle sigorta şirketlerinin yöneticilerinin, muhasebe sistemlerini TMS ile uyumlu hale getirmesine de önemli katkı sağlanmış olacaktır. 


\section{Kaynakça}

Acar, O. (2005). Avrupa Birliğinde yükümlülük karşılama yeterliliği: solvency II. Sigorta Araştırmaları Dergisi, (1), 5.

Akın, F. ve Ece, N. (2013). İMKB'de işlem gören sigorta şirketlerinin 2006-2010 dönemi finansal performanslarının analizi. Muhasebe ve Finansman Dergisi, 57(1), 90-103.

Al-Shami, H. and Ahmed, A. (2008). "Determinants of insurance companies profitability in UAE".College of Business University Utara. Master Thesis, Malaysia.

Çelik, T. (2017). Sigorta şirketlerinde finansal analiz ve bir uygulama. T.C. Marmara Üniversitesi Sosyal Bilimler Enstitüsü. Yüksek Lisans Tezi, İstanbul.

Doğan, M. (2013). Sigorta firmalarının sermaye yapısı ile karlılık arasındaki ilişki. Muhasebe ve Finansman Dergisi, 57(1), 122-136.

Dönmez, E. (2008). Sigorta şirketlerinde muhasebe uygulamaları ve finansal oranların yıllar itibariyle karşılaştırmalı analizi. T.C. Dumlupınar Üniversitesi Sosyal Bilimler Enstitüsü. Yüksek Lisans Tezi, Kütahya.

Ergin, E. (2015). Hisse senedi piyasalarında temel analiz: 2008-2013 yılları arasında BISST'te işlem gören sigorta şirketleri üzerine bir uygulama. T.C. Osmaniye Korkut Ata Üniversitesi Sosyal Bilimler Enstitüsü. Yüksek Lisans Tezi, Osmaniye.

Green, S. B. and Salkind, N. J. (2008). Using SPSS for Windows and Macintosh: Analyzing and Understanding Data. Upper Saddle River: Pearson; Prentice Hall.

Güleç, C. (2015). Türkiye sigorta sektöründe finansal ve teknik rasyo analizi. T.C. İstanbul Aydın Üniversitesi Sosyal Bilimler Enstitüsü. Yüksek Lisans Tezi, İstanbul.

Günkut, M. Ö. (2007). Türk sigorta şirketlerinde mali yeterlilik. Marmara Üniversitesi Sosyal Bilimler Enstitüsü. Yüksek Lisans Tezi, İstanbul.

Hrechaniuk, B., Lutz, S. and Talavera, O. (2007). Do the determinants of insurer's performance in EU and non-EU members differ? http://www.webmeets.com/files/papers/EARIE/ 2007/155/Ins-GLTEARIE.pdf 
Leskay, M. T. (2010). Elementer alanlarda faaliyet gösteren sigorta şirketlerinde finansal tablo analizleri ve bir uygulama. T.C. Dokuz Eylül Üniversitesi Sosyal Bilimler Enstitüsü. Yüksek Lisans Tezi, İzmir.

Özuren, B. R. (2010). Temel performans göstergeleri ile Türkiye'deki hayat dış1 sigorta şirketlerinin karşılaştırmalı analizi. Marmara Üniversitesi Bankacılık ve Sigortacılık Enstitüsü. Yüksek Lisans Tezi, İstanbul.

Süt, S. (2014). Sigorta sektörünün finansal yapısı ve bu yapıya bağlı olarak gelecekteki performans1. T.C. Beykent Üniversitesi Sosyal Bilimler Enstitüsü. Yüksek Lisans Tezi, İstanbul.

Şenyiğit, Y. B. (2010). Sigortacılık sektöründe finansal raporlama ile ilgili uluslararası gelişmeler ve ülkemizde bir araştırma. İstanbul Üniversitesi Sosyal Bilimler Enstitüsü. Doktora Tezi, İstanbul.

Şişmanoğlu, E. (2010). Sigorta şirketlerinde finansal raporlama ve Türkiye finansal raporlama standartlarına geçişin etkilerine yönelik bir araştırma. T.C. İstanbul Üniversitesi Sosyal Bilimler Enstitüsü. Yüksek Lisans Tezi, İstanbul.

The International Financial Reporting Group Of Ernst and Young (2010) International Gaap 2010 Generally Accepted Accounting Practice Under International Financial Reporting Standarts Volume 2. Büyük Britanya: Cpı Williams Clowes Ltd.

Y1lmaz, T. (2010). sigorta sektöründe rasyo analizi yöntemi ile finansal yapının değerlendirilmesi ve İMKB'de İşlem gören sigorta şirketleri üzerine bir uygulama. T.C. Süleyman Demirel Üniversitesi Sosyal Bilimler Enstitüsü. Yüksek Lisans Tezi, Isparta. 


\title{
The Effects of Turkish Accounting Standards (TMS) on Turkish Insurance Sector
}

\author{
Extended Abstract
}

\section{Introduction}

Although insurance companies operate in the financial sector, they are different from other financial institutions in terms of their asset and liability structure. Therefore, the insurance industry needs different accounting practices and financial reporting than other sectors. Due to the need for new regulations for accounting standards in the Turkish insurance industry, "Regulation on Financial Reporting of Insurance and Reinsurance Companies and Pension Companies" was published by the Treasury and Turkey Accounting Standards Board on 01.01.2008. Thus, companies operating in the insurance industry have begun to practise Enterprises Turkey Accounting Standards (TMS). The aim of this research is to determine the effects of TMS on the insurance industry. In the research, firstly, the effects of TMS on the insurance industry are comprehensively explained theoretically. Then by making sector analysis at certain rates, the periods before and after TMS were examined comparatively.

\section{Method}

Two methods were used for the main purposes of the research. These are i) financial ratio analysis and ii) Wilcoxon Signed Ranks Test. Ratio analysis, one of the financial analysis techniques, was used to evaluate the financial ratios obtained from the financial statements of insurance companies operating in the periods before and after TMS for the primary purpose of the research. For the second purpose of the research, Wilcoxon Signed Rank Test, which is one of the non-parametric statistical methods, was used to test whether there is a statistical difference in financial ratios of insurance companies before and after TMS. The calculation of financial ratios from the data obtained from the insurance companies included in the analysis was made with Microsoft Excel program and SPSS 20 Statistical Package Program was used in the statistical analysis of the data.

\section{Results}

According to the findings obtained from financial ratio analysis of the research, it was determined that there was an increase in the Premiums / Total Equity, Liquid Assets / Total Assets, Current Rate, Liquidity, Conservation, Intermediary Commission, Compensation Payment, Cost and Compound Rates with TMS; a decrease in Equity / Asset Total, Equity / Technical Provisions, Capital Adequacy, Premium and Reinsurance Receivables / Asset Total, Technical Reserve, Reinsurance Commission, Premium Increase, Technical Profitability and Return on Equity. According to the findings obtained from the Wilcoxon Signed Ranks Test, there is no difference in terms of the Premiums / Total Equity, Current Ratio, Premium and Reinsurance Receivables / Total Assets, Technical Provision, Premium Increase, Equity Profitability and Technical Profitability Rates between before and after TAS.; there is statistically significant difference in terms of Total Equity / Asset Total, Total Equity / Technical Provisions (Net), Capital Adequacy, Liquid Assets / Asset Total, Liquidity, Compensation Payment, Conservation, Reinsurance Commission, Intermediary Commission, Loss Premium, Asset Profit, Equity Profit and Expense ratios. 


\section{Conclusion}

The main aim of this research is to determine the effects of TMS on the insurance industry. For the aim of the research, 20 sector-specific basic financial ratios of insurance companies operating in non-life branches between 2003-2017 were calculated and comparatively evaluated. Then, it was examined whether there was a statistically significant difference in these rates before TMS (20032007) and after TMS (2007-2017), and their significance levels were tested. When the results obtained in the research are compared with the literature, although there are some studies dealing with the financial structure of insurance companies, it has been determined that there is no study examining the impact of TMS on the insurance sector. It is important that this study is the first for Turkish insurance sector. On the other hand, the most important limitation of the research is that it does not cover insurance companies operating in the life and private pension branches in the Turkish insurance industry between 2003-2017. In future studies on the subject, analyzes can be made using the sectoral data of insurance companies that are not included in the research. 